\section{To: (Receiving Organization) Distribution}

\section{Proj./Prog./Dept./Div.:}

Spent Nuclear Fuel Project

8. Originator Remarks:

For Approval and Distribution

11. Receiver Remarks: 11A. Design Baseline Document? [] Yes [X] No
3. From: (Originating Organization)

Spent Nuclear Fuel Evaluations, $2 T 650$

6. Design Authority/ Design Agent/Cog. Engr.:

$N / A$
4. Related EDT No.:

$N / A$

7. Purchase Order No.:

$N / A$

9. Equip./Component No.:

$\mathrm{N} / \mathrm{A}$

10. System/Bldg./Facility:

$N / A$

12. Major Assm. Dwg. No.:

$N / A$

13. Permit/Permit Application No.:

$N / A$

14. Required Response Date:

$\mathrm{N} / \mathrm{A}$

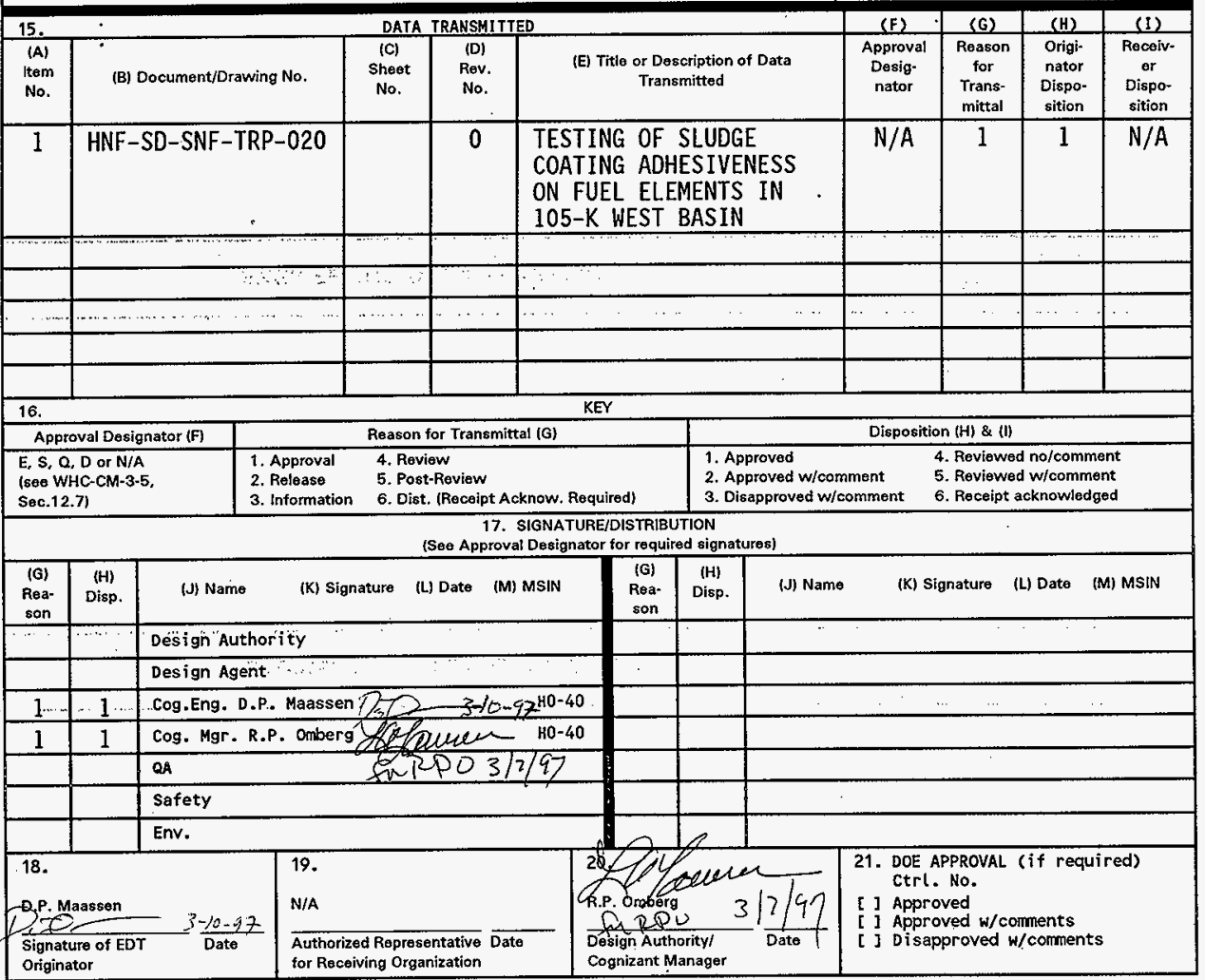




\title{
TESTING OF SLUDGE COATING ADHESIVENESS ON FUEL ELEMENTS IN 105-K WEST BASIN
}

\author{
D. P. Maassen
}

Duke Engineering \& Services Hanford, Inc., Richland, WA 99352

U.S. Department of Energy Contract DE-AC06-96RL13200
EDT/ECN: 620783
UC: 2070
Org Code: 2T650
Charge Code: LB024
B\&R Code: EW7040000
Total Pages: 64

Key Words: 105-K West, Fuel Elements, Surface Coatings, Adhesiveness

Abstract: This report summarizes the results from the first sludge adherence tests performed in the 105-K West Basin on N Reactor fuel. The outside surface of the outer fuel elements were brushed, using stainless steel wire brushes, to test the adhesiveness of various types of sludge coatings to the cladding's surface. The majority of the sludge was removed by the wire brushes in this test but different types of sludge were more adhesive than others. Particularly, an orange rust-like sludge coating that was just slightly more adherent to the fuel's cladding than the majority of the sludge coatings and a thick white vertical strip sludge coating that was much more difficult to remove. The test demonstrated that all of the siudge could be removed from the outer fuel elements' surfaces if the need arises.

TRADEMARK DISCLAIMER. Reference herein to any specific commercial product, process, or service by trade name, trademark, manufacturer, or otherwise, does not necessarily constitute or imply its endorsement, recommendation, or favoring by the United States Government or any agency thereof or its contractors or subcontractors.

Printed in the United States of America. To obtain copies of this document, contact: Document Control Services, P.O. Box 950, Mailstop H6-08, Richland WA 99352, Phone (509) 372-2420; Fax $(509) 376-4989$.
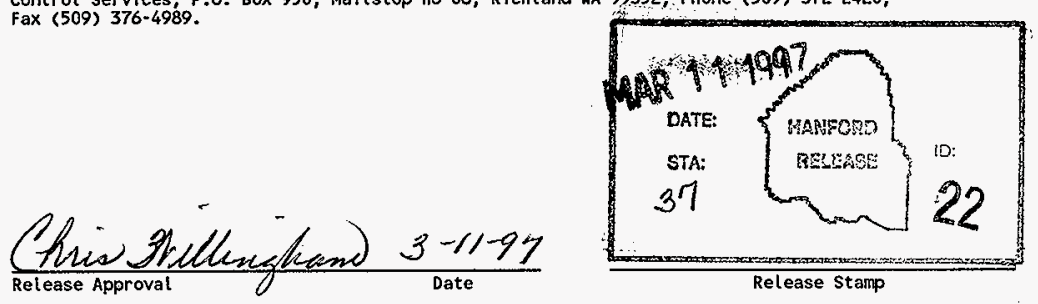
HNF-SD-SNF-TRP-020, Rev, 0

\section{EXECUTIVE SUMMARY}

The contents of the $K$ Basins consists primarily of $N$ Reactor fue $]$ assemblies each of which contain an outer and inner fuel element. The outer surfaces of $\mathrm{N}$ Reactor outer fuel elements stored in the $\mathrm{K}$ West Basin were cleaned by wire brushes to test the adhesiveness of different types of sludge coatings. These results will aid in the design of cleaning methods in the event that the chemical composition of the sludge coatings determine that there removal is necessary for the preparation of the fuel for dry storage. The report also discusses the different types of sludge coatings tested and how the 105-K West fuel coatings compares to the 105-K East fuel coatings evaluated previously. Selected outer fuel elements were placed in the Fuel Element Brush Assembly (FEBA) to test the adherence characteristics of the sludge coatings on the outside surfaces of the fuel element. The rating of adhesiveness was based on how well the FEBA removed the sludge coatings.

The different types of sludge coatings that were visually observed on the outer fuel elements were organized into the following categories of appearance: (1) a thin white film that covered the whole fuel element;

(2) an orange rust-like coating that covered the whole element; (3) white streaks that ran vertically on the fuel element; (4) rust-like substance on the spacers that spread onto the surface of the cladding; (5) nodules that were white circular debris that formed on the cladding of the fuel element when in contact with the canister; (6) black spots that formed on the cladding; and (7) yellowish-green film that developed in small locations on the cladding. 
HNF-SD-SNF-TRP-020, Rev. 0

\section{EXECUTIVE SUMMARY (Continued)}

The fuel elements were brushed only part way leaving a transition area that could be examined for thoroughness of the cleaning by the FEBA. Most types of sludge coatings were easily removed; however, two types of sludge were more difficult to remove. The orange rust-like sludge that covered most of an outer fuel element was removed during the testing but had a bigger transitional area than the other type of sludge coatings. This demonstrated stronger adhesiveness characteristics than the other types of sludge coatings. The most adhesive type of sludge coating, in the context of these tests, was the type of thick white coating that ran vertically on the fuel element. This coating was very adhesive but seemed brittle in behavior. This type of sludge coating was not removed during the testing but most likely would have if the brushing had been extended. It did seem that this type of sludge could be chipped off rather than brushed. 
HNF-SD-SNF-TRP-020, Rev. 0

\section{CONTENTS}

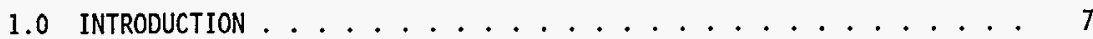

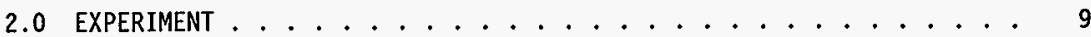

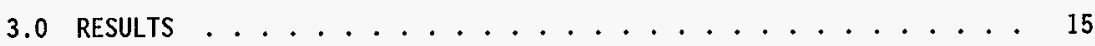

4.0 DISCUSSION OF RESULTS ........................... 27

5.0 COMPARE AND CONTRAST WITH $K$ WEST FUEL BRUSHING TO $K$ EAST FUEL

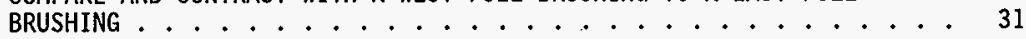

6.0 CONCLUSION ............................ 35

7.0 REFERENCES ......................... 37

APPENDIX A SUPPORTING DOCUMENT (INTERNAL MEMORANDUM) ...... 39 


\section{LIST OF FIGURES}

1. The Fuel Element Brush Assembly Before Entering the Waters of 105-K West Basin .............. 8

2. Schematic of the Transfer Channel and South Loadout Pit of the 105-K West Basin ............. 10

3. Top and Front Sketch Views of the Fuel Element Brush Assembly which was Used in 105-K West .............. 11

4. Sketch of the Brushing Work Area . . . . . . . . . . . . 12

5. Picture of the Brushing Work Area . . . . . . . . . . . . 13

6. Unmarked Barrel of 5744 Canister--Element \#5 Before, During, After, and Transition Area of Brushing . . . . . . . 16

7. Unmarked Barrel of 5744 Canister--Element \#3 Before, During, After, and Transition Area of Brushing ......... 17

8. Unmarked Barrel of 2667 Canister--Element \#2 Before, During, After, and Transition Area of Brushing . . . . . . . . . 19

9. Unmarked Barrel of 2667 Canister--Element \#4 Before, After, During, and Transition Area of Brushing . . . . . . . . . 20

10. Marked Barrel of 0161 Canister--Element \#7 Before, After, During, and Transition Area of Brushing . . . . . . . . 22

11. Unmarked Barrel of 1164 Canister--Element \#3 Before, After, During, and Transition Area of Brushing . . . . . . . . . 23

12. Marked Barrel of 1497 Canister--Element \#1 Before, After, During, and Transition Area of Brushing .........

13. Marked Barrel of 1497 Canister--Element \#6 Before, After, During, and Transition Area of Brushing . . . . . . . . . 26

14. A Freshly Autoclaved Fuel Element Before it was put into the Reactor............... 30

15. Outer Fuel Element in 105-K East Before, After, During, and Transition Area of Brushing .......... 
HNF-SD-SNF-TRP-020, Rev. 0

\section{LIST OF TABLES}

1. Fuel Elements that were Brushed in 105-K West Basin . . . . . . 25

2. The Different Types of Sludge Coatings and Adhesiveness Results in 105-K East and 105-K West ........... 28 
HNF-SD-SNF-TRP-020, Rev. 0

This page intentionally left blank. 
HNF-SD-SNF-TRP-020, Rev. 0

\section{TESTING OF SLUDGE COATING ADHESIVENESS \\ ON FUEL ELEMENTS IN 105-K WEST BASIN}

\subsection{INTRODUCTION}

This test was designed and conducted to determine the adhesiveness of surface sludge coatings on outer $\mathrm{N}$ Reactor fuel elements in the 105-K West Basin. Sludge coatings have formed on the cladding of each fuel element during long term storage in the basins. It is not known how the sludge coatings formed on the cladding, but they have been observed on the cladding of the fuel elements inspected. If the chemical composition of the sludge coatings warrants removal from the fuel elements, the data presented in this report will provide information to the integrated water treatment system and the fuel retrieval designs. The sludge, if easily removed, could affect water treatment systems and fuel retrieval by: (1) increasing the contamination in the basin; (2) diffusing throughout the basin; (3) limiting sight of the floor of the basin; (4) contaminating the systems created to retrieve, clean, and store the fuel elements; and (5) increasing radioactive dose. If the sludge coatings have different physical or chemical characteristics than the fuel elements, the sludge may need to be separated from the fuel and dispositioned differently for long-term storage. The results from this test will al so be used to answer some of the questions in the "Data Quality Objectives (DQO) for the Second K West Fue1 Examinations," (Lawrence 1997). These question are:

1. How adherent are the coatings and can they be easily removed?

2. Is the adherent $K$ West sludge similar in quantity and behavior to corresponding sludge on $\mathrm{K}$ East elements?

Selected 105-K West fuel elements were recovered from the closed canisters during the second fuel sampling campaign and cleaned on the outer surface with a wire brush to determine the behavior of the different types of materials adherent to the fuel element's cladding. The testing was based on how well the Fuel Element Brush Assembly (FEBA), shown in Figure 1, removed the sludge coating. The results of adhesiveness were subject to the uncertainty of the actual mechanical work being done to the sludge coating by the FEBA because the data was established from visual observations of brushing selected elements in the basin.

The testing was started on January 22, 1997 and completed on January 23, 1997. A17 the work was done manually by the operators at the $K$ Basins. Fuel elements were removed from closed canisters and brought to the FEBA by using a fuel element handling tool. The operator then physically pushed and pulled the fuel elements in and out of the FEBA to clean the outside of the fuel elements. The fuel elements were then placed back into the host canisters and resealed.

This report describes the tests performed on sludge coatings that are adherent to the fuel elements. This report does not comment on the free sludge that is present in the basin or in the storage canisters. Throughout this report the term "sludge". is used in reference to the sludge coatings and not free sludge accumulating in the basin. 
Figure 1. The Fuel Element Brush Assembly Before Entering the Waters of 105-K West Basin. The four pictures show the front, top, bottom, and side views of the FEBA.

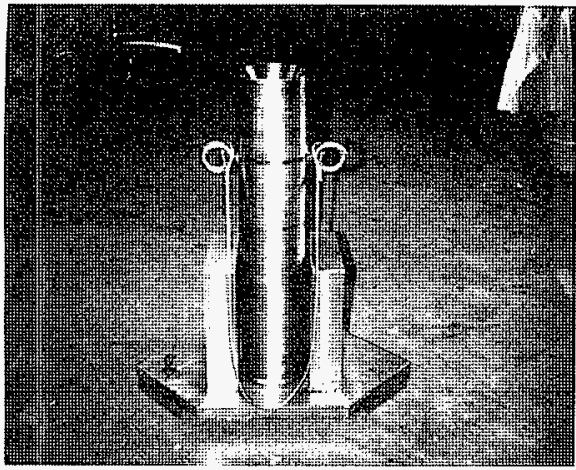

Front View

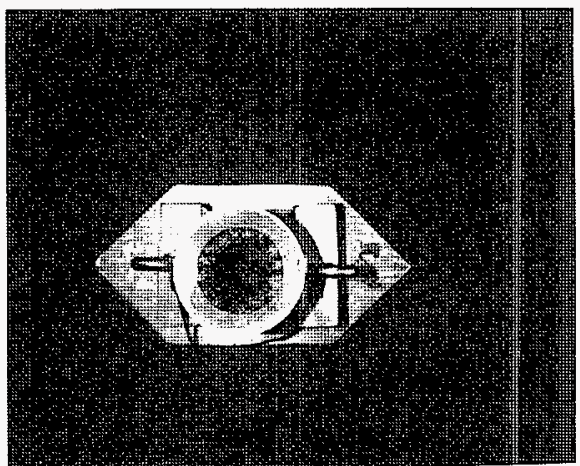

Top View

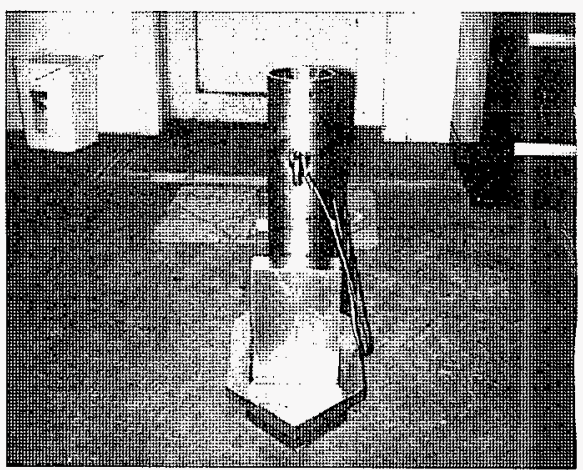

Side View 
HNF-SD-SNF-TRP-020, Rev. 0

\subsection{EXPERIMENT}

The fuel elements that were brushed were in the $K$ West Basin. The contents of the $K$ West Basin consisted primarily of $N$ Reactor fuel assemblies, each of which contain an outer and inner fuel element. The only locations where those fuel elements could be brushed, due to the process standard PCA-304-B3, were in the transfer channel or in the South loadout pit of the $K$ West Basin. A schematic of the work location is shown in Figure 2. The $K$ West Basin leads into a small opening that is called the transfer channel which contains the decapping station (where the canister lids are removed) and two storage racks for canisters. The transfer channel then leads to the South loadout pit which is five feet deeper than the transfer channel. Because of the depth of the South loadout pit, the best location to do the experiment was in the transfer channel. A FEBA was designed and fabricated to fit into a storage rack inside the transfer channe?. A sketch of the dimensions of the FEBA is shown in Figure 3. The FEBA utilized stainless steel brushes to scrub the outside of an outer fuel element. A sketch and picture of the testing equipment in operation is shown in Figures 4 and 5 .

The brush tested if the sludge coatings that had been collecting on the fuel in the 105-K West Basin could be removed by the continuous mechanical work of the brush against the sludge and fuel surface.

Al1 of the operations that were conducted in the test were done by operations personnel at 105-K West and instructed by procedure 0P-07-108W. Fuel canisters that were identified by internal memorandum (Makenas 1997) were brought into the transfer channel's decapping station from the $K$ West Basin. The Internal Memorandum, "Recommended $K$ West Basin Canisters for Fuel Element Retrieval (Second Campajgn)," is in Appendix A. Each of the canisters' fuel elements that were identified had been previously visually inspected as part in the Phase II characterization campaign for 105-K West (Pitner 1997). The 1 id was removed from one of the canister's barrels and a inner fuel element was removed from the outer fuel element by an inner fuel element handling tool (H-1-81566, Rev, 0). After the inner fuel element was removed, the outer fuel element was retrieved by the outer fuel element handling tool (H-1-80533, Rev. 1) and examined via cameras in the transfer channel. The decision was made to brush the element or return it to its storage location. Three test engineers examined the elements and based their decision whether or not to brush on the following: (1) good physical integrity, as to not break in the FEBA; and (2) have a unique type of sludge or characteristic that made it a good candidate to brush. If it was determined that a fuel element had a distinctive or different kind of sludge characteristic (than that was already brushed from another fuel element), the fuel element was transferred to the FEBA via operator to be brushed. The fuel element was brushed only on the bottom portion of the fuel element to create a point that could be compared after the brushing. The operator would push the fuel element down into the FEBA and then bring it back up about 10 times and if necessary the operator would twist the fuel element inside the FEBA to assure the entire circumference of the element was being covered by the bristles of the FEBA. After brushing, the fuel element was returned and examined for the adherence properties of the fuel element's surface sludge. After the visual inspection of the outer fuel elements, the outer and inner fuel elements were returned to the storage canister. 
HNF-SD-SNF-TRP-020, Rev. 0

Figure 2. Schematic of the Transfer Channel and South Loadout Pit of the 105-K West Basin.

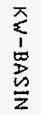

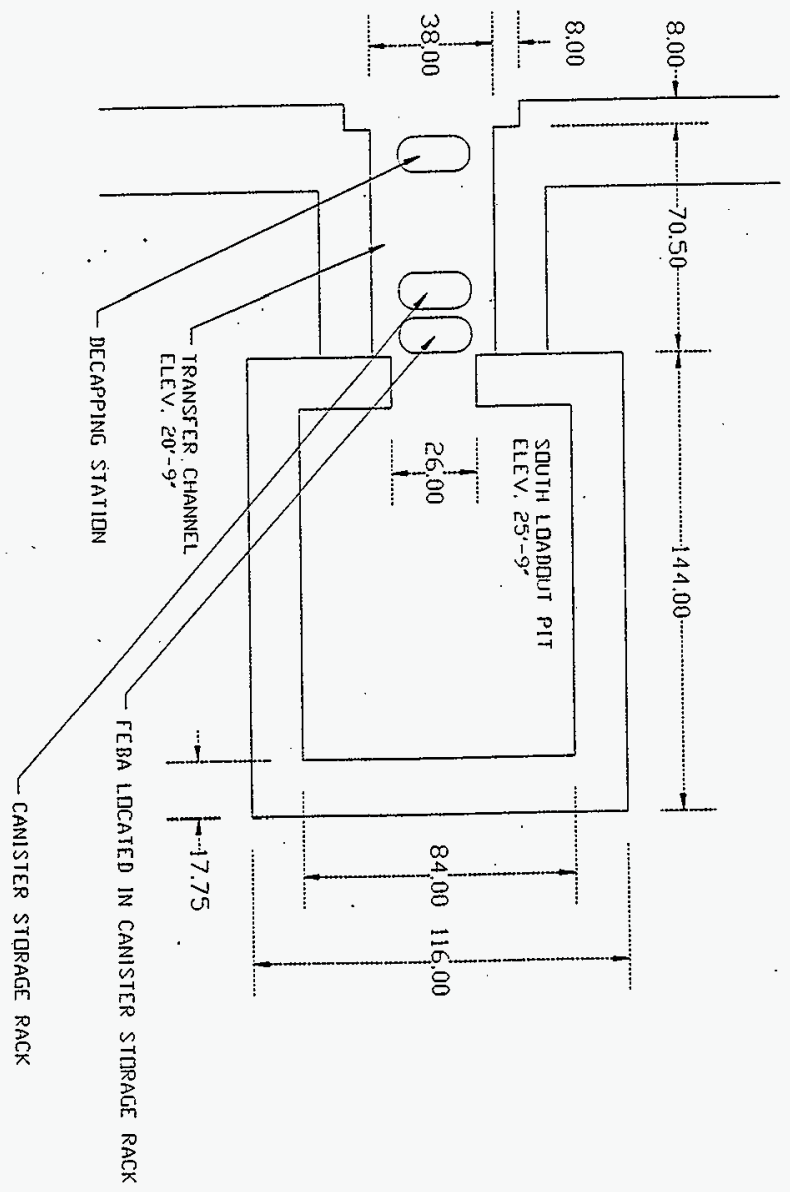


Figure 3. Top, Front, and Isometric Sketch Views of the Fuel Element Brush Assembly which was Used in 105-K West.
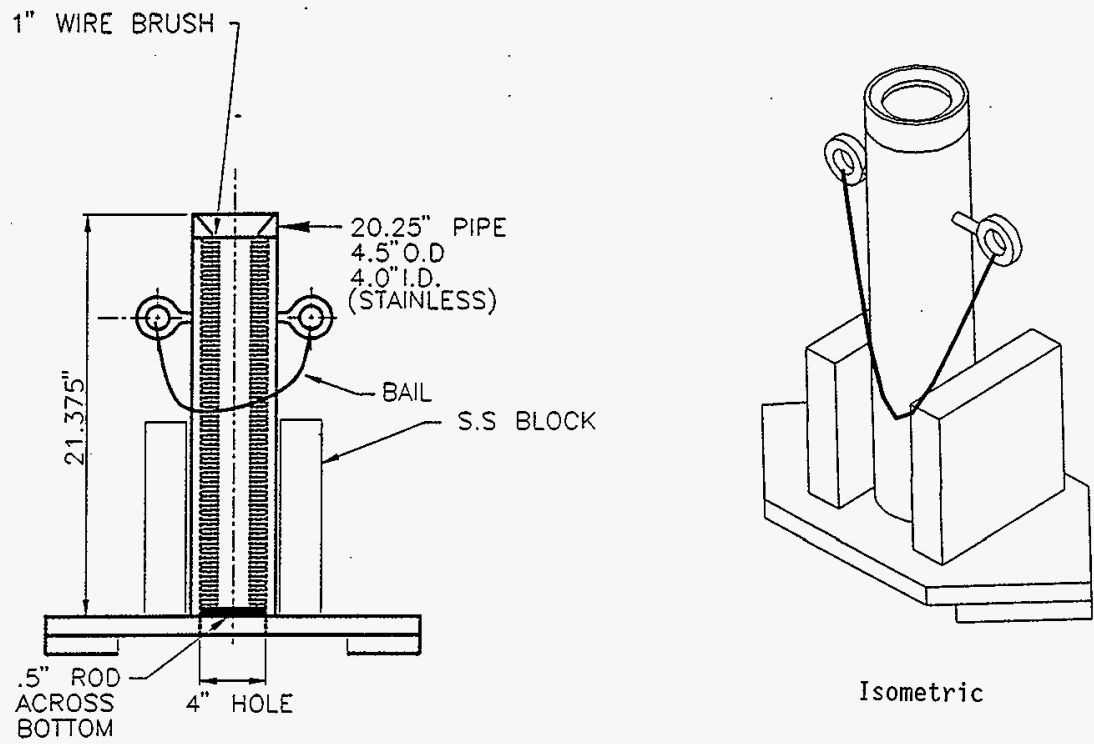

Front

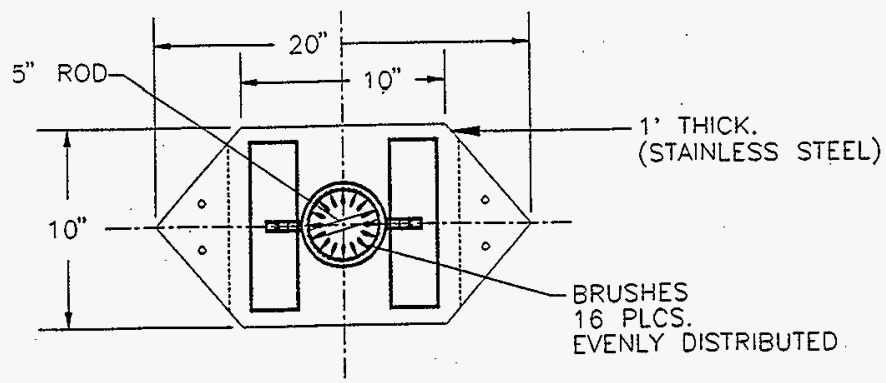

Top 
Figure 4. Sketch of the Brushing Work Area. The sketch shows the fuel handling tool, fuel element, canister rack, camera, operator, and the Fuel Element Brush Assembly.

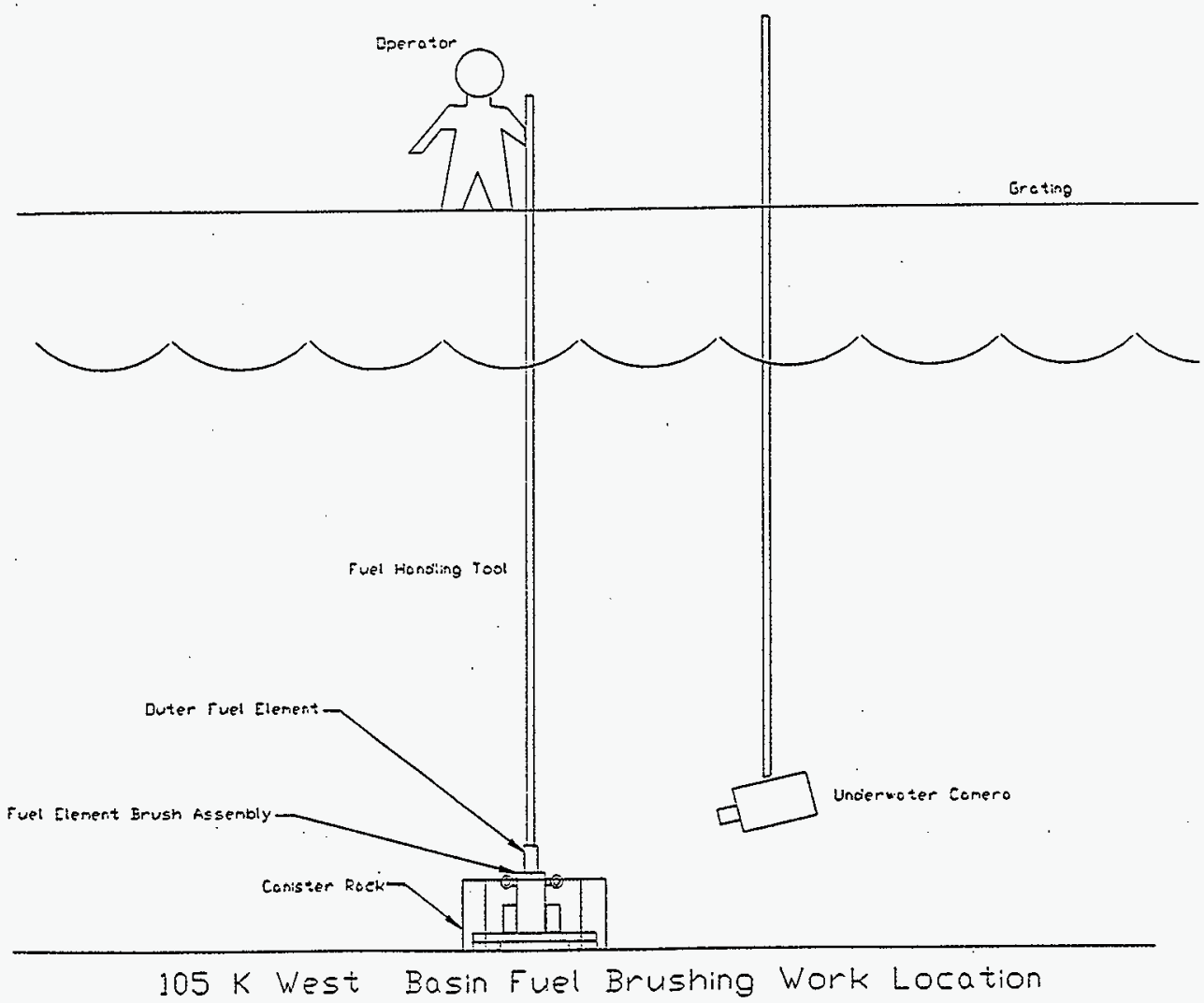


HNF-SD-SNF-TRP-020, Rev. 0

Figure 5. Picture of the Brushing Work Area.

Outer Fuel Element Hand ing Tool

(H-1-80533, Rev. 1)

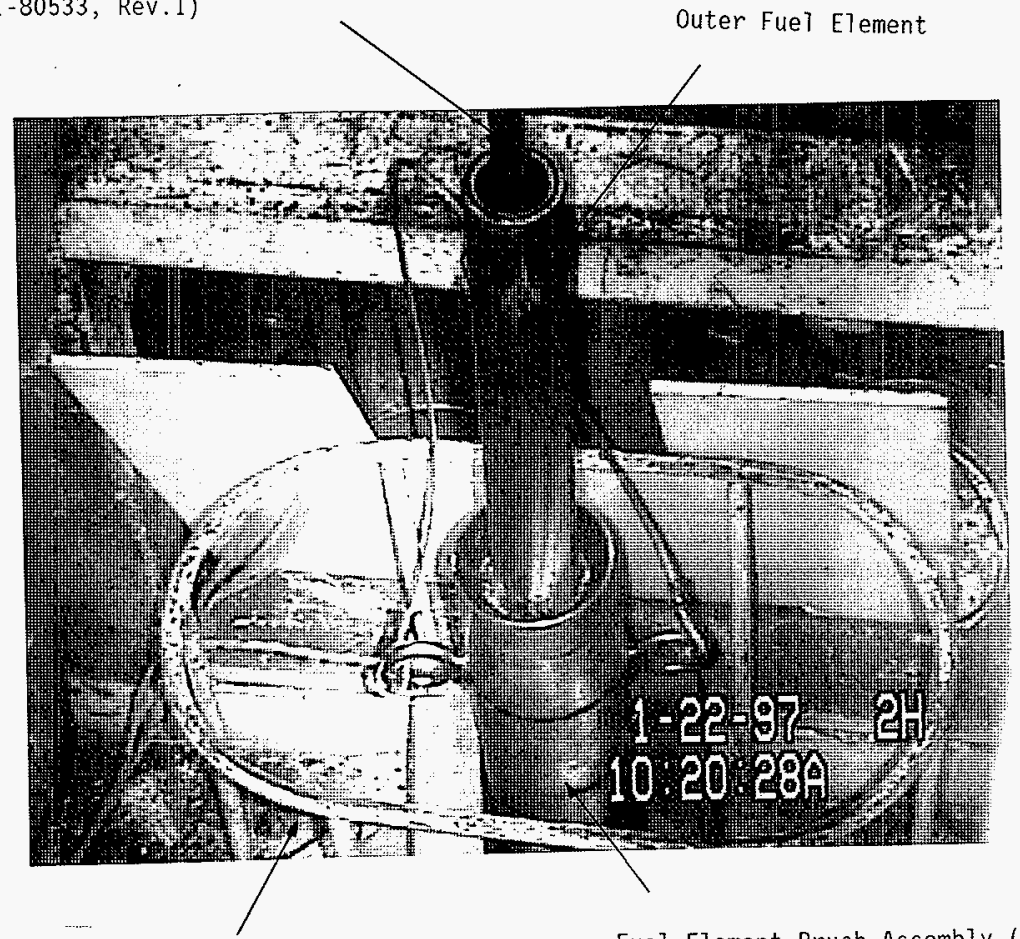

Canister Storage Rack

Fuel Element Brush Assembiy (FEBA) 
HNF-SD-SNF-TRP-020, Rev. 0

This page intentionally left blank. 


\subsection{RESULTS}

Table 1 identifies the eight fuel elements that were brushed during 105-K West sludge adherence testing (Makenas 1997; Short 1995). Pictures of fuel elements prior to brushing, during brushing, and after brushing (including the brushed to non-brushed transition area of the fuel elements) are shown in specified figures. The pictures were taken from the video tape that documented the brushing test. The colors referenced in this repart are taken from the video footage. The video cameras were not calibrated for color and may not be true. The various video cameras used in the test were located at different distances from the fuel elements which caused color shifts due to the refraction of the light through the water.

The first element taken was from the unmarked barrel of canister 5744 and was identified as the element in position \#5. Pictures of the fuel element are shown in Figure 6 . The element positions were numbered as one being next to the trunion and the rest numbered in order clockwise with seven being in the middle. The element was visually examined and had an orange coating which appeared to be rust forming around the spacers. The fuel element also had a yellowish-green $f i 1 m$ forming up from two of the spacers. There were spots of white residue around the bottom of the fuel element as well as spots of rustlike coating forming on the cladding. There were black lines that form around the bottom of the fuel element and there was a thin white film all around the outside of the outer element. Also, there were surface scratches that ran all the way up and down the element making it a good candidate to brush. The fuel element was brushed 16 times with some twisting of the element in the FEBA at the end. The fuel element was basically clean after three brush strokes. However, brushing continued for thoroughness. It was very apparent that sludge was being removed by the FEBA because of a heavy plume of debris that was ejected into the basin water out of the FEBAs top orifice. The fuel element was only placed about half way into the FEBA to see a contrast between the brushed half and the non-brushed half. All of the sludge came off except the rust-like coating that was behind the spacers where the brushes could not reach. There was a noticeable difference between the half that had been brushed and the half that had not. Since the film was off the fuel element, it was observed that the scratches on the surface of the fuel element were actually cracks in the cladding and a bristle of the brush was actually stuck in one of the hair-line cracks. The cracks in the element appeared to have spiral pattern that progressed up the fuel element with breaks in the cracks continuity. This could be the result of internal corrosion of the fuel. There were still some scratches that remained on the fuel element so all the apparent scratches where not cracks but a combination of both cracks and scratches. There were still some small shiny spots that appear to be dents or abrasions on the cladding surface.

The second element that was brushed was the element in position \#3 of the same barrel as the first element. Pictures of the fuel element are shown in Figure 7 . The element had some rust-1ike coating around the spacers and more of the green-yellowish film than on the first element brushed, plus there were some white blemishes on the surface of the cladding where the fuel element was resting against the canister that were routinely called canister biisters. 
Figure 6. Unmarked Barrel of 5744 Canister---Element \#5 Before, During, After, and Transition Area of Brushing.

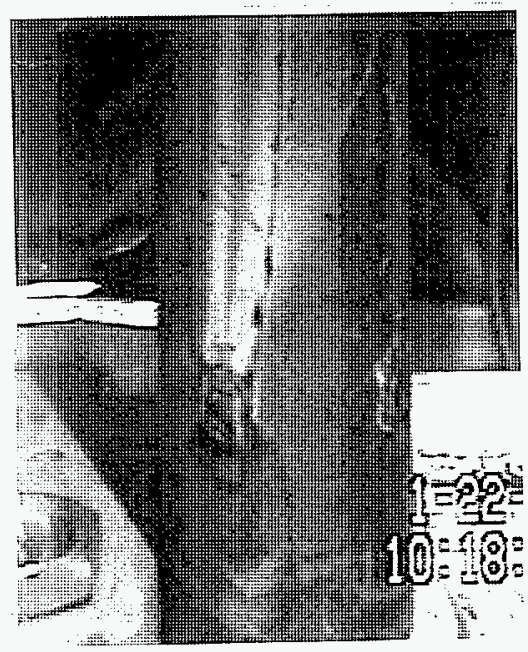

Before

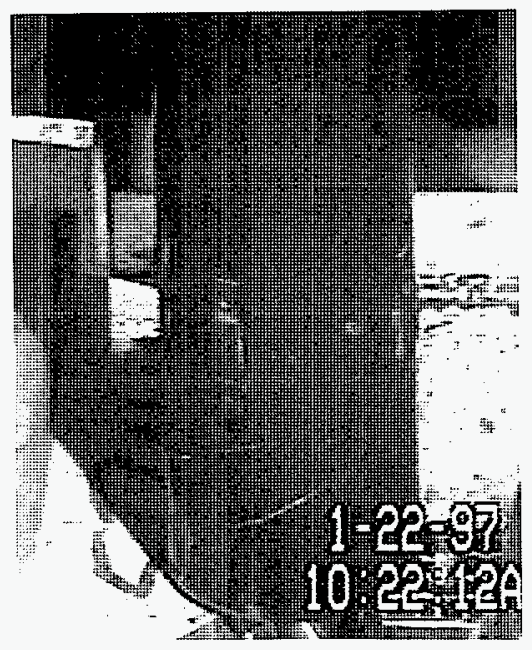

After

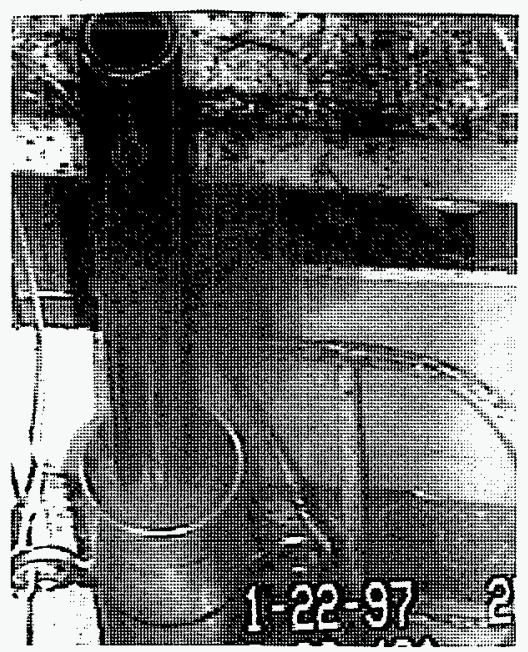

During

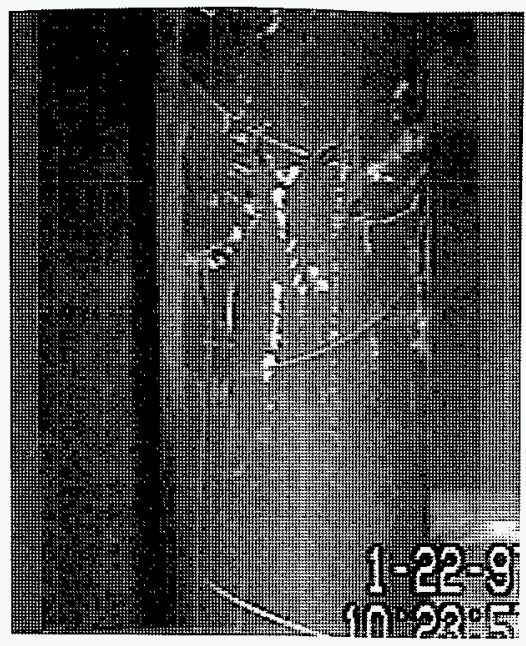

Transition Area 
Figure 7. Unmarked Barre] of 5744 Canister--Element \#3 Before, During, After, and Transition Area of Brushing.

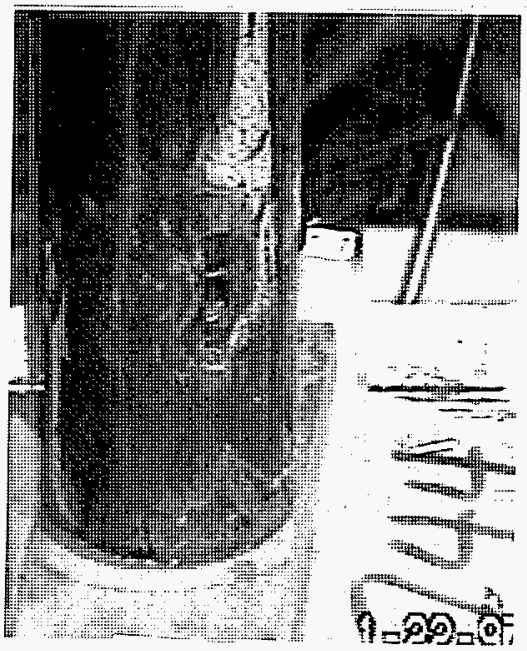

Before

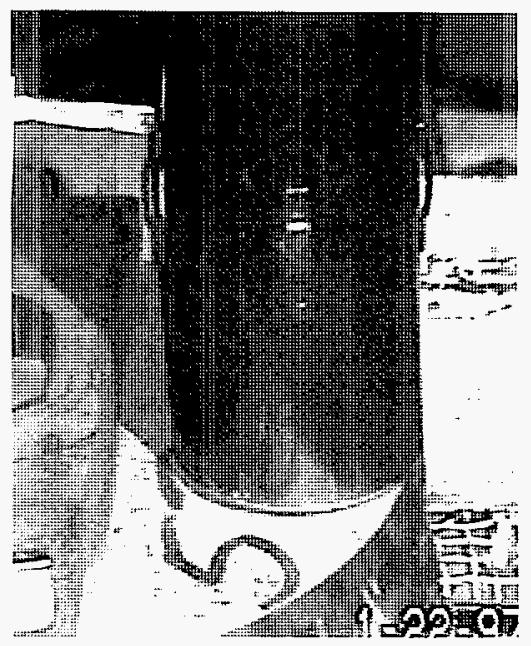

After

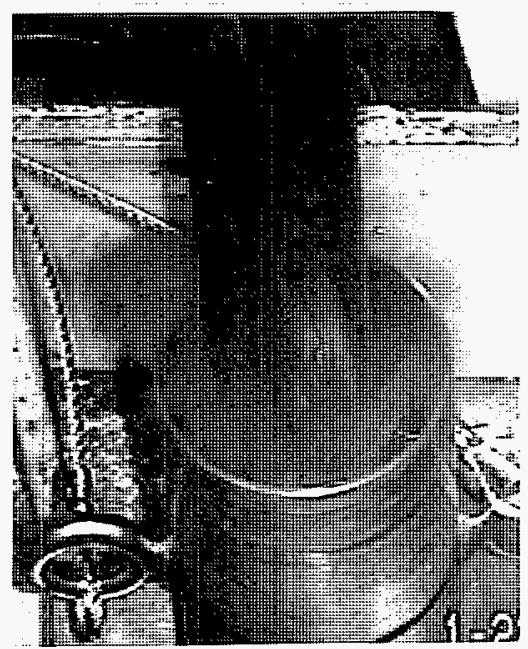

During

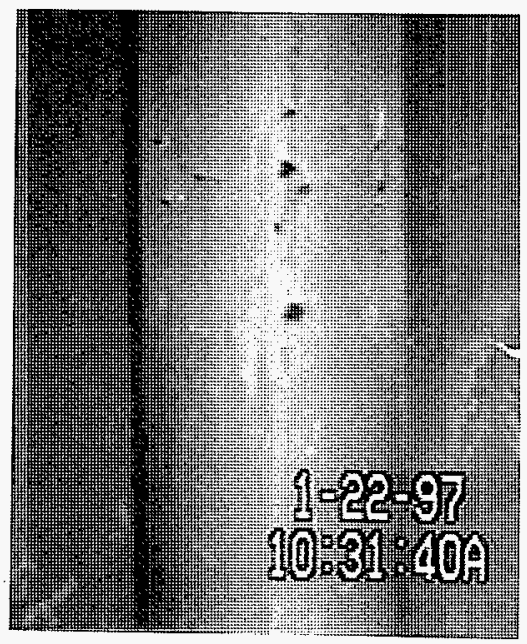

Transition Area 
HNF-SD-SNF-TRP-020, Rev. 0

There were dark spots in the fuel element's coating that appeared to be the cladding surface. A thin white film covered part of the element, with some thin white streaks that were formed in a vertical direction on the fuel element and some black streaks that appeared in various locations on the cladding. The fuel element was brushed 13 times in the FEBA but was clean after three strokes. The rust-like coating (except inside the spacers), the green-yellowish film, and the canister blisters were all removed. There were no visible cracks to the cladding but some scratches that were not visible before brushing were visible after brushing. The brushed half of the fuel element was a shiny, bright black indicative of zirconium oxide which was a distinct contrast to the non-brushed half. There were still some small shiny spots that appeared on the cladding surface. They seemed to be dents or abrasions on the cladding possibly occurring during discharge from the reactor.

The third element brushed was element \#2 taken from the unmarked barre1 of canister 2667. Pictures of the fuel element are shown in Figure 8 . It had a reddish-brown coating that looked like rust with some spots of cladding showing or a black coating on the cladding. The coating on the spacers appeared to be the same substance but had a brighter color than the sludge coating on the fuel element itself. There were no visible cracks in the cladding before brushing but there were thin bright yellow streaks that ran vertically along the fuel element. The fuel element was brushed 12 times with a 360 degree twist. All of the strokes were needed to clean the element. There was more sludge on this particular fuel element than the other two fuel elements that were brushed and it was obvious that the FEBAs bristles did not cover the entire element with the same force. The fuel element was twisted inside the FEBA in order to remove residual sludge coating streaks that developed due to the lack of force from the sides of the bristles. It took longer to remove this type of sludge but this was probably because of the quantity of sludge that was on the surface of the cladding and may not necessarily be due to the type of sludge. There was a brownish mist in the water from the sludge that was removed from the fuel element. After brushing, the fuel element looked clean at the bottom, but had a large transition zone. Vertically up the fuel element there appeared to be black spots on the surface of the cladding. This was an indicator that this type of sludge coating was harder to remove from the fuel element's surface than the other types of sludge coatings previously observed. The transitional area of the fuel element was increased because the bottom half of the fuel element was brushed more frequentiy than a higher portion of the fuel element. The transitional part of the fuel element contained two different sludge coating colors: the outer coating was a rust-like coating, and the inner coating was a yellowishgreen color that formed on the cladding. The bottom of the fuel element had similar visual characteristics as the first two elements brushed, i.e., with a shiny, bright black color. While moving upwards on the fuel element, it contained a progression of thicker yellowish-green film that still remained. The yellowish-green film would most likely be removed with more brushing by the FEBA.

The fourth element was from the same barrel as the third and was the element in position \#4. Pictures of the fuel element are shown in Figure 9. The element had the same sludge characteristics as the third element but it 
HNF-SD-SNF-TRP-020, Rev. 0

Figure 8. Unmarked Barrel of 2667 Canister--Element \#2 Before, During, After, and Transition Area of Brushing.

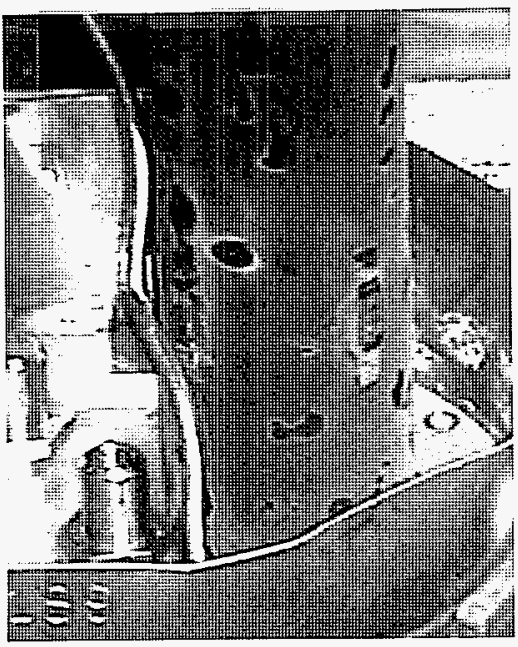

Before

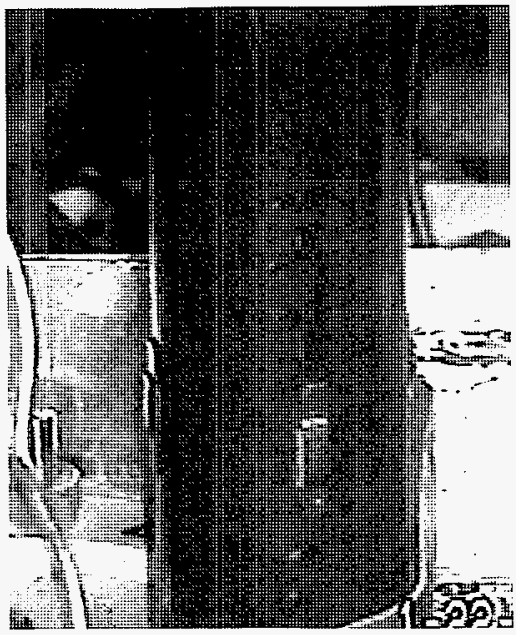

After

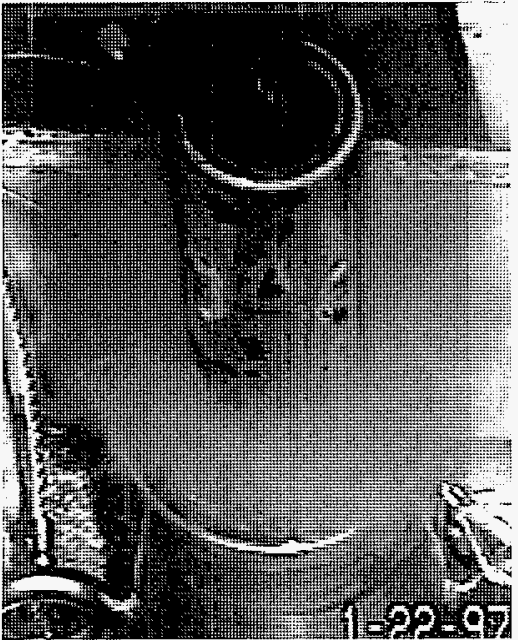

During

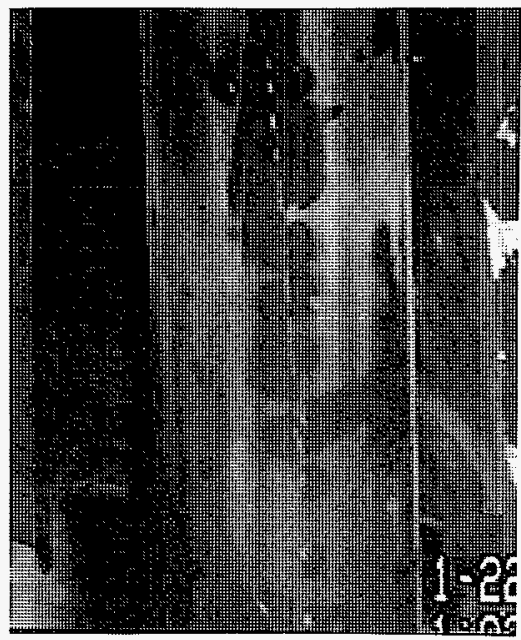

Transition 
Figure 9. Unmarked Barre] of 2667 Canister--Element \#4 Before, After, During, and Transition Area of Brushing.

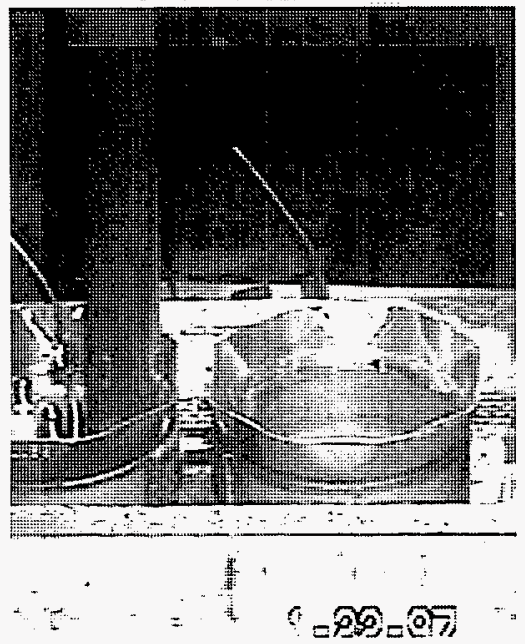

Before

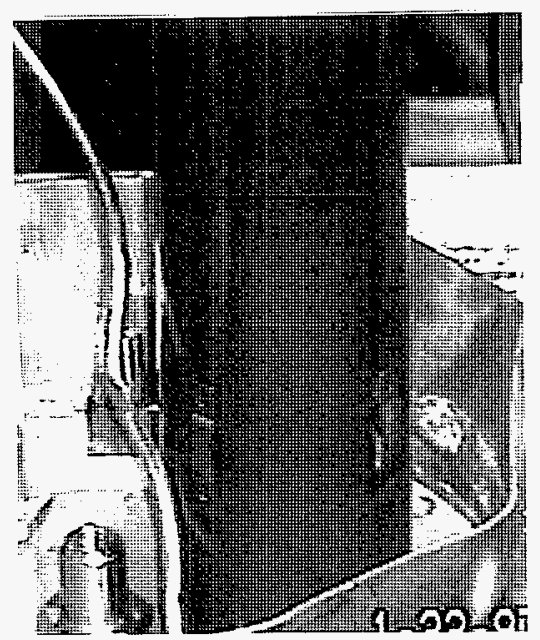

After

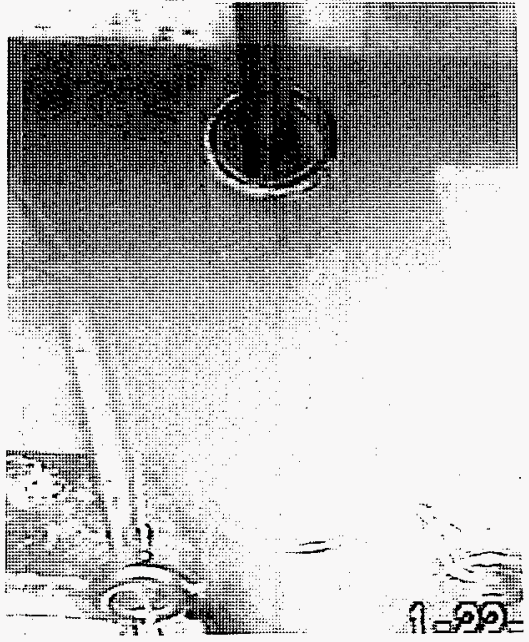

During

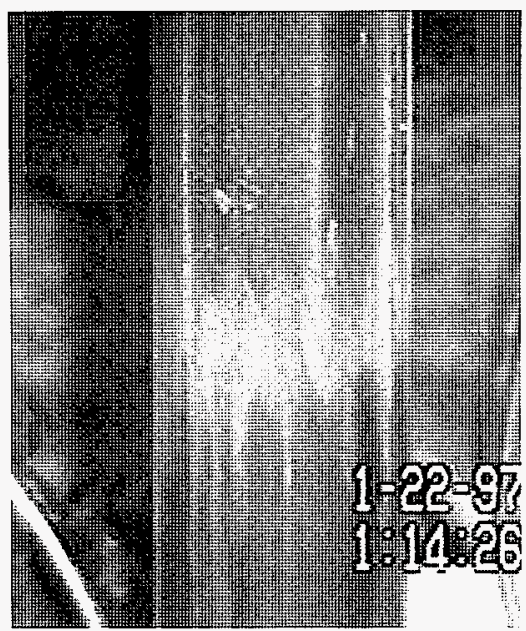

Transition Area 
Figure 10. Marked Barrel of 0161 Canister--Element \#7 Before, After, During, and Transition Area of Brushing.

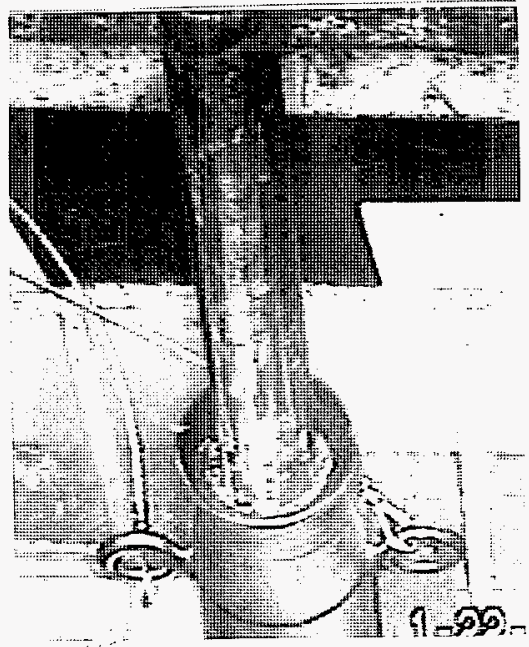

Before
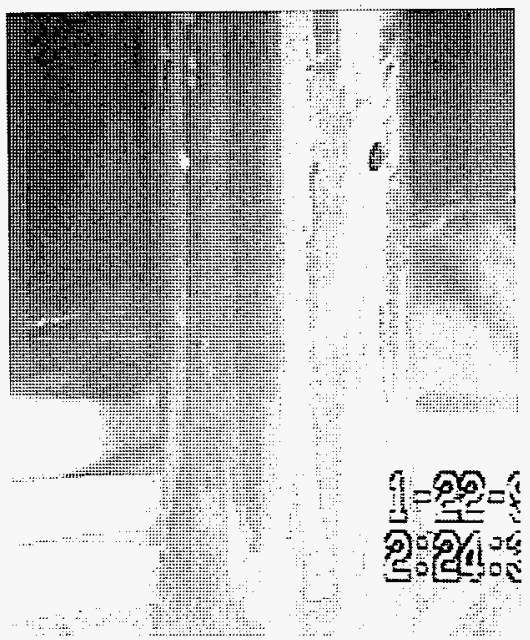

After

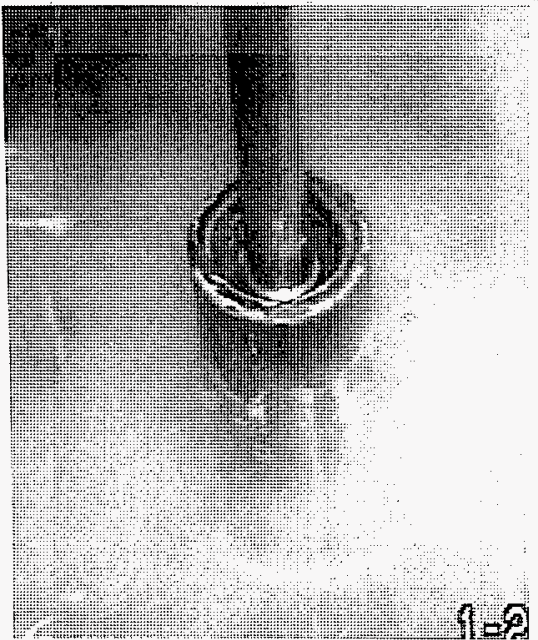

During

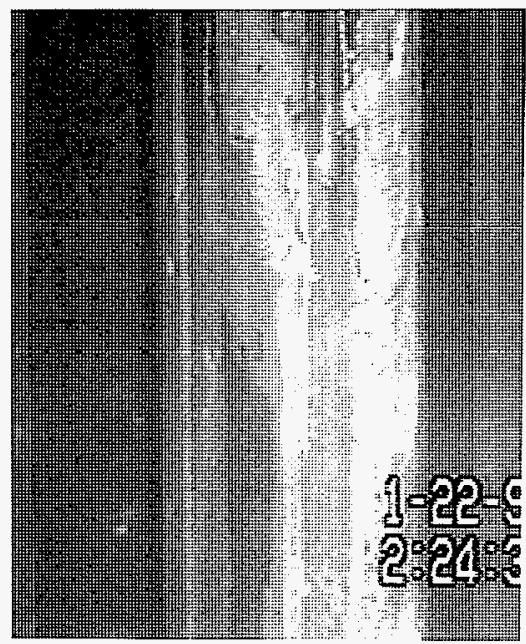

Transition Area 
Figure 11. Unmarked Barrel of 1164 Canister--Element \#3 Before, After, During, and Transition Area of Brushing.

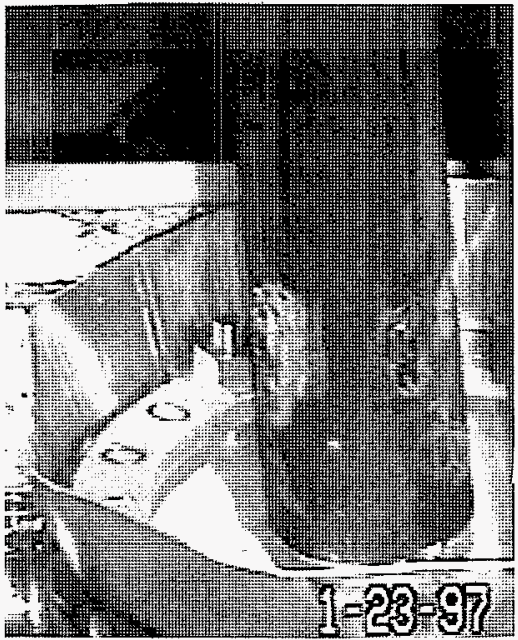

Before

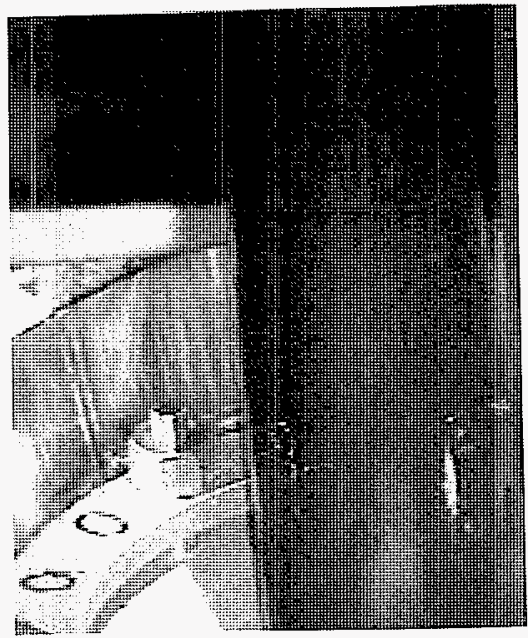

After

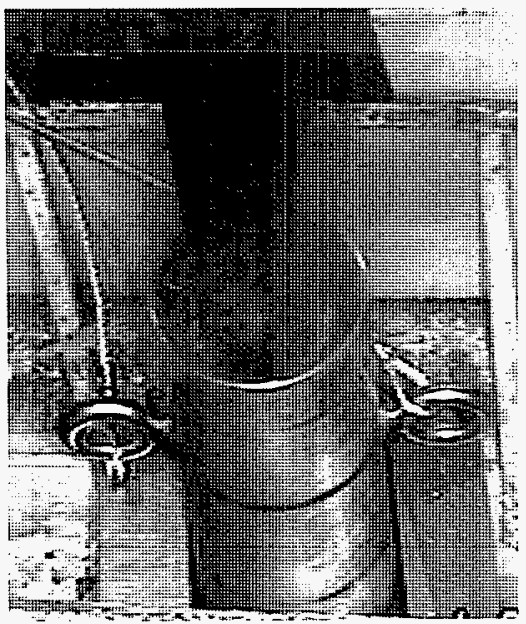

During

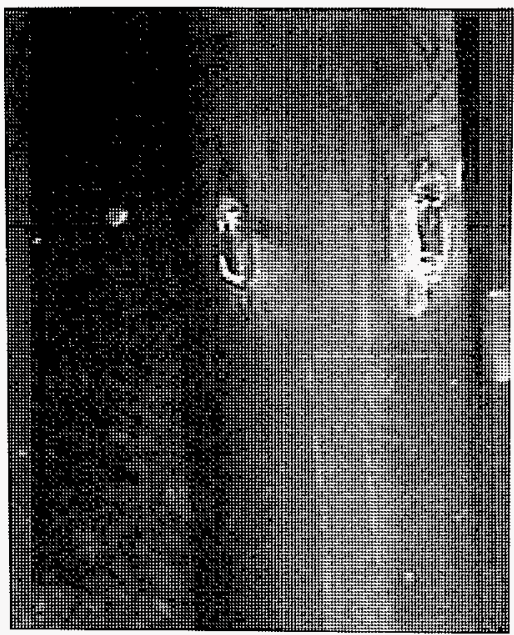

Transition Area 
Figure 12. Marked Barrel of 1497 Canister--Element \#1 Before, After, During, and Transition Area of Brushing.

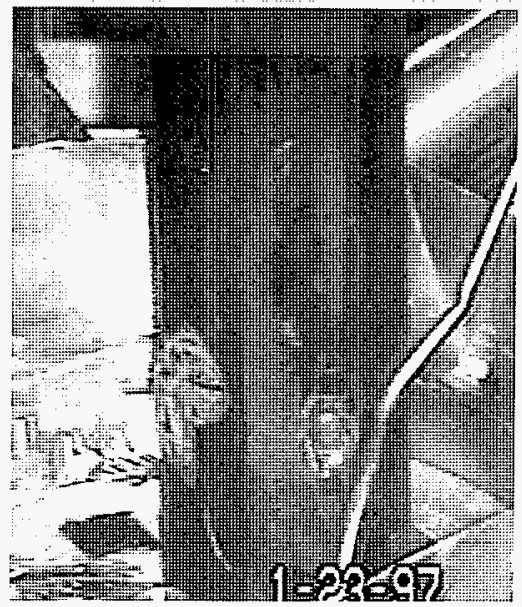

Before

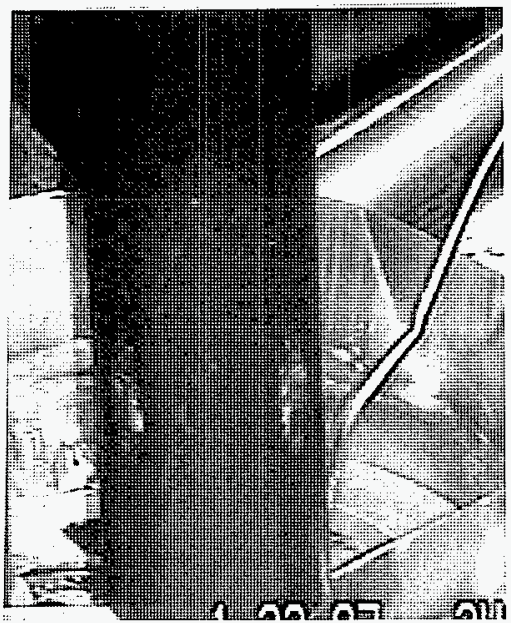

After

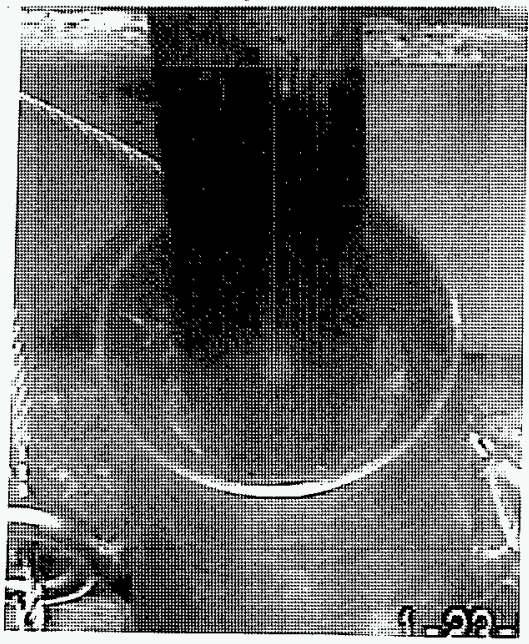

During

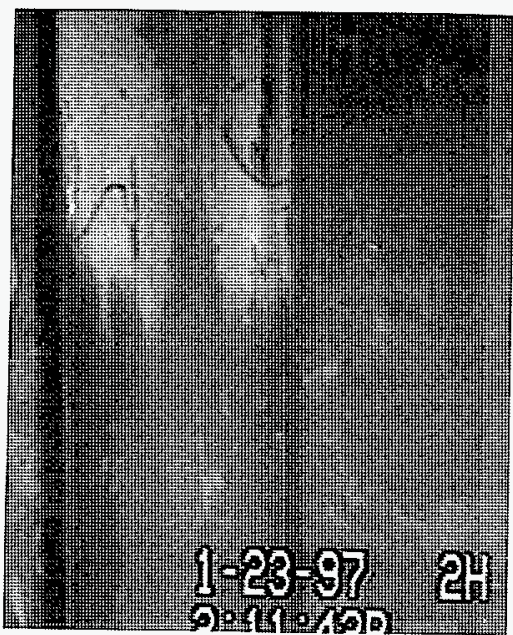

Transition Area 
The eighth element was from the same barrel as the seventh and was in position \#6. Pictures of the fuel element are shown in Figure 13. Before brushing, the fuel element had a streak of white residue on the cladding that looked like the same substance as the fifth element brushed but with less thickness. There were some visible dents on the cladding of the fuel element, and the cladding was covered with a lighter film. The fuel element was brushed and created a brown cloud in the water with a small white highlight from the white streak. After three brushings and one 360 degree twist, the white streak, the rust, and the white film that covered the fuel element were removed. The fuel element was clean which made the dents even more visible than before.

Table 1. Fuel Elements that were Brushed in 105-K West Basin.

\begin{tabular}{|c|c|c|c|c|c|c|c|}
\hline $\begin{array}{l}\text { Order of } \\
\text { Brushing }\end{array}$ & $\begin{array}{c}\text { Canister } \\
\text { Number }\end{array}$ & Location & $\begin{array}{l}\text { Element } \\
\text { Number }\end{array}$ & $\begin{array}{c}\text { Canister } \\
\text { Type }\end{array}$ & $\begin{array}{c}\text { Final } \\
\text { Result }\end{array}$ & $\begin{array}{l}\text { Fue } \\
\text { Type }\end{array}$ & $\begin{array}{c}\text { Fuel } \\
\text { Mode1 } \\
\text { Code } \\
\end{array}$ \\
\hline 1 & $5744 \mathrm{U}$ & 4511 & 5 & MKII & $\begin{array}{l}\text { Sludge } \\
\text { removed }\end{array}$ & MKIA & $\mathrm{AM}^{1}$ \\
\hline 2 & $5744 U$ & 4511 & 3 & MKII & $\begin{array}{l}\text { Sludge } \\
\text { removed }\end{array}$ & MKIA & $\mathrm{AM}^{1}$ \\
\hline 3 & $2667 U$ & 2923 & 2 & MKI & $\begin{array}{l}\text { Sludge } \\
\text { removed }\end{array}$ & MKIA & $A M^{1}$ \\
\hline 4 & 26670 & 2923 & 4 & MKI & $\begin{array}{l}\text { Sludge } \\
\text { removed }\end{array}$ & MKIA & $A M^{1}$ \\
\hline 5 & 0161M & 2913 & 7 & MKI & $\begin{array}{l}\text { Sludge } \\
\text { not } \\
\text { removed }\end{array}$ & MKIA & $\mathrm{AM}^{1}$ \\
\hline 6 & $1164 \mathrm{U}$ & 3619 & 3 & MKI & $\begin{array}{l}\text { Sludge } \\
\text { removed }\end{array}$ & MKIA & $A M^{1}$ \\
\hline 7 & $1497 \mathrm{U}$ & 3839 & 1 & MKI & $\begin{array}{l}\text { Sludge } \\
\text { removed }\end{array}$ & MKIA & $\begin{array}{l}\mathrm{AM}^{1} \\
\text { or } \\
\mathrm{AT}^{2}\end{array}$ \\
\hline 8 & 14970 & 3839 & 6 & MKI & $\begin{array}{l}\text { Sludge } \\
\text { removed }\end{array}$ & MKIA & $\begin{array}{l}A M^{1} \\
o r \\
A T^{2}\end{array}$ \\
\hline
\end{tabular}

${ }^{1} A M$ stands for the specific fuel, the $A$ means it is MKIA type fuel and the $M$ stands for length of 20.9 in.

${ }^{2}$ AT stands for the specific fuel, the $A$ means it is MKIA type fue 1 and the $T$ stands for length of 19.6 in. 
Figure 13. Marked Barrel of 1497 Canister--Element \#6 Before, After, During, and Transition Area of Brushing.

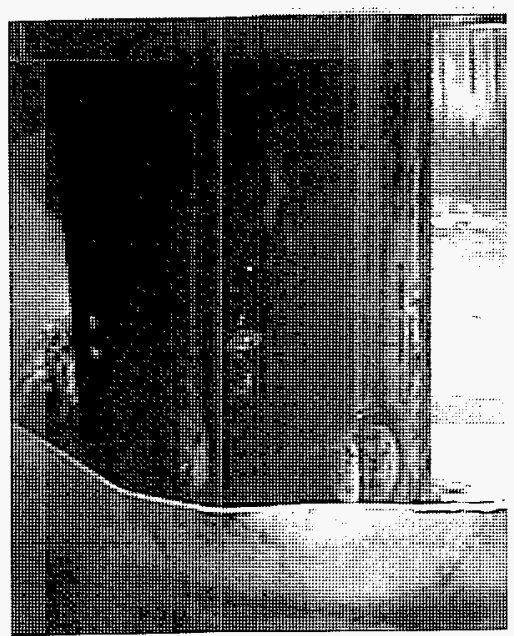

Before

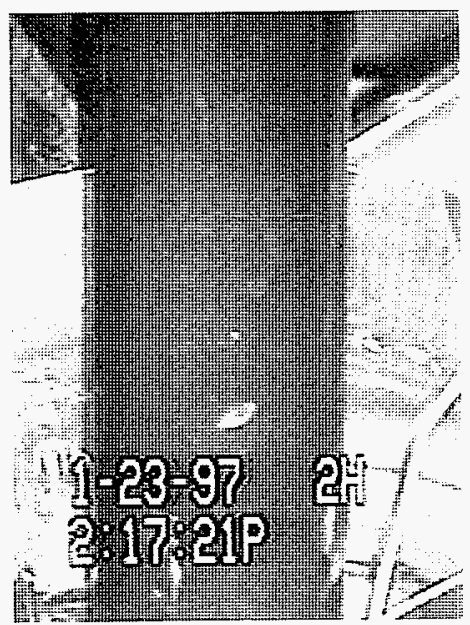

After

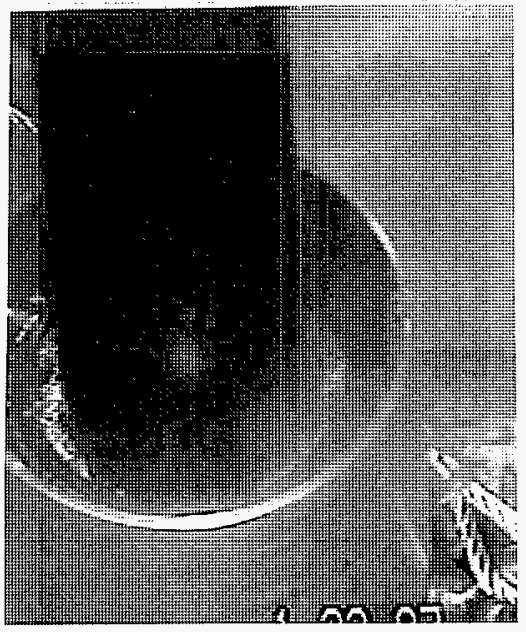

During

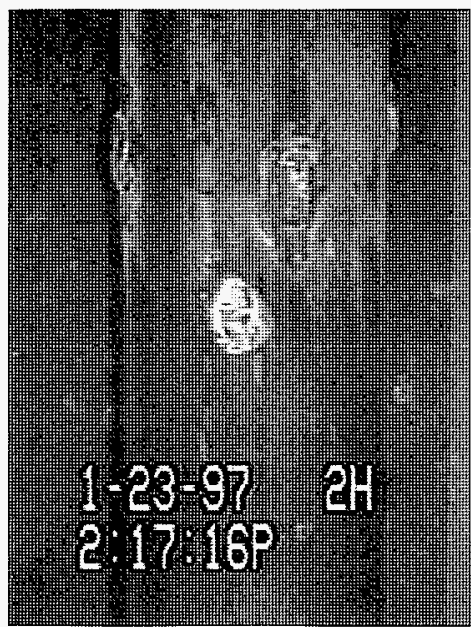

Transition Area 
HNF-SD-SNF-TRP-020, Rev. 0

\subsection{DISCUSSION OF RESULTS}

The different types of sludge coatings are summarized in Table 2. The sludge coatings that were subject to brushing can be categorized into seven basic groups: (1) A thin white film that covered the entire fuel element; (2) an orange coating that covered the whole element; (3) white streaks that ran vertically on the fuel element; (4) rust-like coating on the spacers that spread onto the surface of the cladding; (5) white blemishes or nodules that were white circular debris formed on the cladding of the fuel element when in contact with the canister; (6) black spots that formed on the cladding; (7) yellowish-green film that developed in small locations on the cladding.

The thin white film seemed to be very easily removed along with the rust-like film on the spacers, nodules, white streaks, and the yellowish-green film. The thin white film exhibited the potential to camouflage or hide cracks in the cladding. The first fuel element brushed was a good example of the thin white film's camouflaging effect to cracks. It was not very easy to see the cracks before brushing but there were definitely cracks in the cladding visible after brushing. This could mean visually characterized unbrushed fuel elements could be more damaged than they first appeared.

The white blemishes (a.k.a nodules or canister blisters) were only seen on the second fuel element tested. The nodules appeared to be formed where the fuel element was in contact with the canister. The canister was a stainless steeT, MKII type canister.

The orange coating, that appeared to be rust, covered almost all of the third and fourth fuel elements brushed and was removed by the FEBA. It took a twist of the element in the FEBA to remove the orange sludge but it was removed. The orange sludge changed colors to a yellowish-green while brushing. This could have happened due to a change in thickness or the yellowish-green sludge was a second coating below the rust-like coating. The second and third fuel elements brushed were compared because a similarity of the yellowish-green sludge coating. This was observed when looking at the transition area of the third element brushed compared to the second element before brushing. On the second fuel element, the yellowish-green sludge that appeared next to the rust-liked spacer looked similar to the yellowish-green sludge that was on the transitional area of the brushed third element. One could assume that the orange sludge formed over the top of the yellowish-green sludge or that the orange color formed after an increase in thickness.

The black spots that were on the third element's cladding were believed to be areas that the orange sludge did not adhere to the cladding. After brushing the third element, there were still black spots that appeared. This may indicate that some of the coating was still left on the element. It is believed that after more brushing, the fuel element would eventually become clean as evidenced from the bottom of the same fuel element. The bottom of the fuel element was brushed about four more times and it was very clean with no evidence of the film being on the fuel element and with no black spots. 
Table 2. The Different Types of Sludge Coatings and Adhesiveness Results in 105-K East and 105-K West.

\begin{tabular}{|c|c|c|c|}
\hline Basin & $\begin{array}{l}\text { Order of } \\
\text { Brushing }\end{array}$ & Description of STudge Coatings & Final Result \\
\hline K East $^{1}$ & 1 & $\begin{array}{l}\text { 1. Dark ring on bottom of element } \\
\text { 2. Rust-like sludge on spacers } \\
\text { 3. Multi-colored sludge } \\
\text { (yellow,green, etc.) covering } \\
\text { most of the element } \\
\text { 4. Nodules }\end{array}$ & 1. Sludge removed \\
\hline$k$ West & 1 & $\begin{array}{l}\text { 1. Scratches on cladding } \\
\text { 2. Rust-like sludge on spacers } \\
\text { 3. Multi-colored sludge } \\
\text { (yellowish-green) } \\
\text { 4. Thin layer of film }\end{array}$ & 1. Sludge removed \\
\hline K West & 2 & $\begin{array}{l}\text { 1. Rust-like sludge on spacers } \\
\text { 2. Multi-colored sludge } \\
\text { (yellowish-green) } \\
\text { 3. Nodules } \\
\text { 4. Thin layer of film }\end{array}$ & 1. Sludge removed \\
\hline K West & 3 & $\begin{array}{l}\text { 1. Reddish brown coating all over } \\
\text { the element looked like rust } \\
\text { that covered the spacers } \\
\text { 2. Black spots of cladding }\end{array}$ & $\begin{array}{l}\text { 1. Sludge removed } \\
\text { 2. Large transitional } \\
\text { area }\end{array}$ \\
\hline K West & 4 & $\begin{array}{l}\text { 1. Reddish brown coating all over } \\
\text { the fuel element looked like } \\
\text { rust that covered the spacers }\end{array}$ & $\begin{array}{l}\text { 1. Sludge removed } \\
\text { 2. Large transitional } \\
\text { area }\end{array}$ \\
\hline K West & 5 & $\begin{array}{l}\text { 1. White debris stuck to the } \\
\text { cladding in streaks } \\
\text { 2. Thin layer of white film }\end{array}$ & $\begin{array}{l}\text { 1. More difficult } \\
\text { to removed } \\
\text { 2. White cloud }\end{array}$ \\
\hline$K$ West & 6 & $\begin{array}{l}\text { 1. Rust-like sludge on spacers } \\
\text { 2. Thin layer of film that dulled } \\
\text { the color of the fuel element }\end{array}$ & 1. STudge removed \\
\hline K West & 7 & $\begin{array}{l}\text { 1. Rust-like sludge on spacers } \\
\text { 2. Thin layer of film that dulled } \\
\text { the color of the fuel element }\end{array}$ & 1. STudge removed \\
\hline $\mathrm{K}$ West & 8 & $\begin{array}{l}\text { 1. Rust-like sludge on spacers } \\
\text { 2. Streaks of white debris } \\
\text { 3. Dents in cladding } \\
\text { 4. Thin white film on cladding }\end{array}$ & 1. Sludge removed \\
\hline
\end{tabular}

The $K$ East fuel element was brushed after it had been rocked and rolled in a cylinder. The rock and roll motion had no effect on the sludge adhesiveness. 
The heavy white streaks that appeared on the fifth element seemed to be a brittle type of sludge that flaked off rather than brushed off. The sludge did not entirely come off with the FEBA. Actually, very little of the sludge came off of the fuel element. The sludge that came off was evident by small sections of the sludge that flaked off and by the brushing dulling the surface of the sludge. It appeared that the sludge would come off the fuel element by a lot of continuous brushing or by chipping at the sludge coating.

There was another type of sludge that consisted of white streaks on the eighth fuel element brushed. This type of sludge looked the same as the sludge on the fifth element brushed but not as thick. The fifth element's sludge that was brushed seemed to be cemented on the fuel element while the eighth element brushed seemed to be lightly coated with sludge. This type of sludge came off relatively easy and was no problem for the FEBA.

After the fuel elements were brushed, the outer surface of the elements appeared smooth and dark, very similar to, if not the same as, a freshly autoclaved fuel element as shown in Figure 14. The only difference between the brushed spent nuclear fuel outer elements and the freshly autoclaved fuel elements were scratches and dents that probably occurred to the spent nuclear outer fuel elements when discharged from the reactor or during in-basin handling. The brushing demonstrated that most of the sludge coatings were not aggressively adhering to the fuel and that they could be removed by mechanical work. However, two of the sludge coating types were more difficult to remove with the brush. It is believed that an increase in the amount of mechanical work on these materials would ultimately remove these coatings. The sludge itself was very fine; it diffused through the water at a very slow rate and seemed to exhibit a long settling time. 
HNF-SD-SNF-TRP-020, Rev. 0

Figure 14. A Freshly Autoclaved Fuel Element Before it was put into the Reactor.

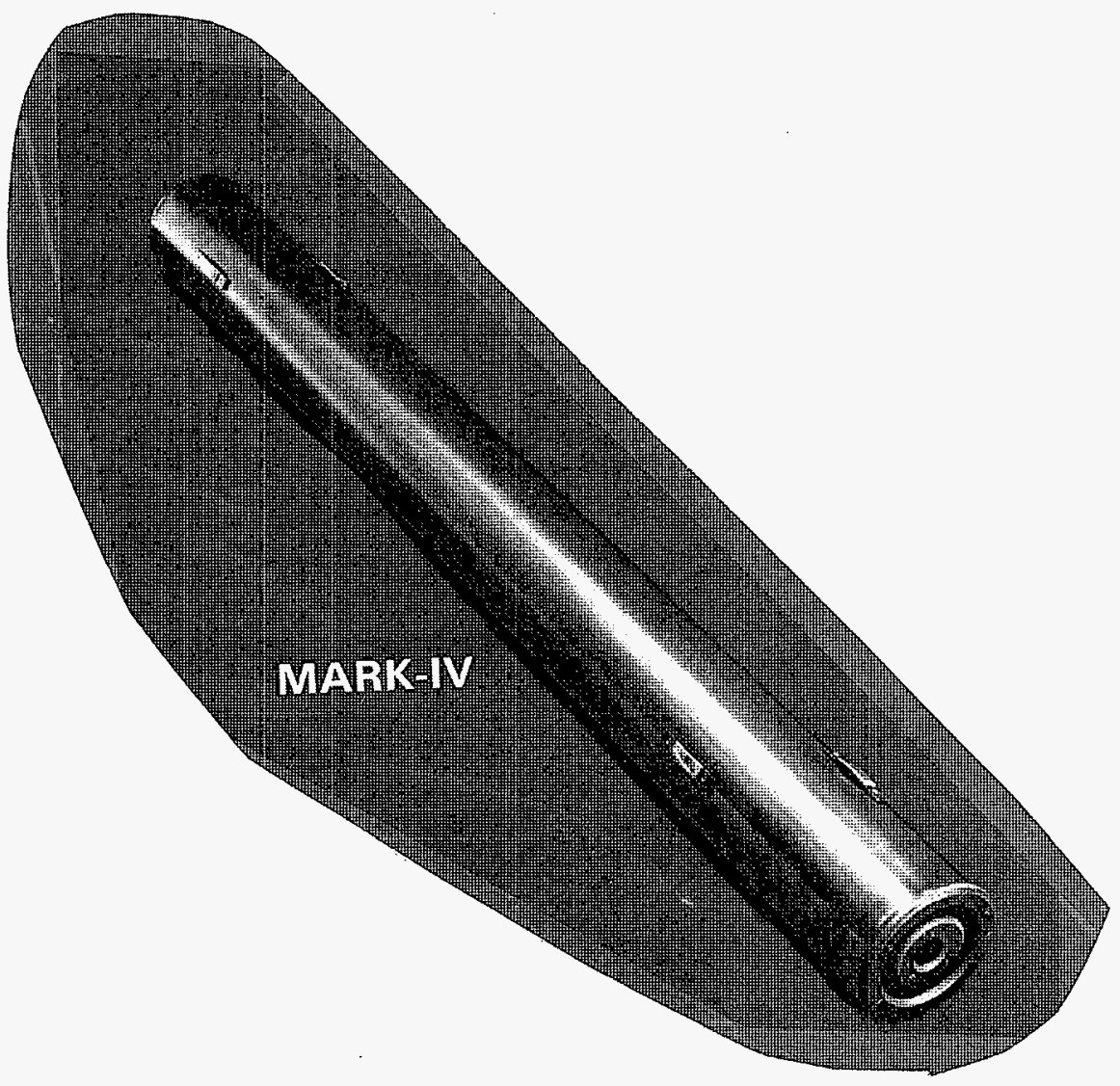


HNF-SD-SNF-TRP-020, Rev. 0

\subsection{COMPARE AND CONTRAST WITH $K$ WEST FUEL. BRUSHING TO $K$ EAST FUEL BRUSHING}

The comparison of the testing in 105-K West to the testing done in 105-K East showed little difference. A summary of the results are shown in Table 2. The testing done from 105-K East is summarized in a report titled "Sludge Adherence Summary Report" (WHC-SD-SNF-TRP-015, Rev. 0). The testing with a brush in 105-K East was done to one fuel element which was an outer, but it had four different kinds of sludge that are described below. The pictures of the outer $K$ East fuel element are shown in Figure 15.

The K-East fuel element was covered in a light colored sludge (Bergmann 1996) similar to the sludge that was on elements 1 and 2 from 105-K West, but with more quantity. Elements 1 and 2 only had spots on the cladding where this type of sludge coating accumulated; but the fuel element from 105-K East was totally covered with this type of sludge, except at the bottom tip of the fuel element where another type of sludge formed (Bergmann 1996).

The other type of sludge that formed on the bottom tip of the $K$ East outer fuel element was a dark ring of sludge (Bergmann 1996); this was because the fuel element was submerged in sludge that settled at the bottom of the canister. This type of sludge was less prevalent in the $K$ West Basin. This was best explained by 105-K West having less floor sludge than in 105-K East. In addition, the canisters in 105-K West are sealed with lids while the canisters in 105-K East are open having no lids, plus some of the canisters in $K$ East are Mark 0 canisters which have grating for the bottom and allow floor debris and sludge to settle inside the canister in contact with the fuel. $K$ West, however, contains Mark I and Mark II canisters which have solid bottoms and stop the floor debris and floor sludge from coming into contact with the fuel. It should also be noted that the dark ring of sludge is of unknown composition and could represent an absence of sludge coating due to the fact that the floor sludge covered the bottom of the fuel elements and prevented a more adhesive sludge coating from forming on the fuel elements. For these reasons, there were no dark sludge rings found on the fuel elements visually inspected or brushed in 105-K West.

The $K$ East fuel element spacers appeared to be rusted just like many of the spacers from the fuel elements in $K$ West.

The last form of sludge found on the fuel element tested in $K$ East was nodules that formed where there was direct contact between the cladding and the fuel storage canister (Bergmann 1996). This type of sludge was also found in $K$ West on the second fuel element.

All of the sludge was removed from the fuel element in $K$ East (Bergmann 1996) but that can not be said of the sludge in $K$ West. A single fuel element, the fifth element tested, had a thick white coating that could not be removed by the FEBA. This type of sludge was not seen in the $K$ East test. 


$$
\text { HNF-SD-SNF-TRP-020, Rev. } 0
$$

Figure 15. Outer Fuel Element in 105-K East Before, After, During, and Transition Area of Brushing.

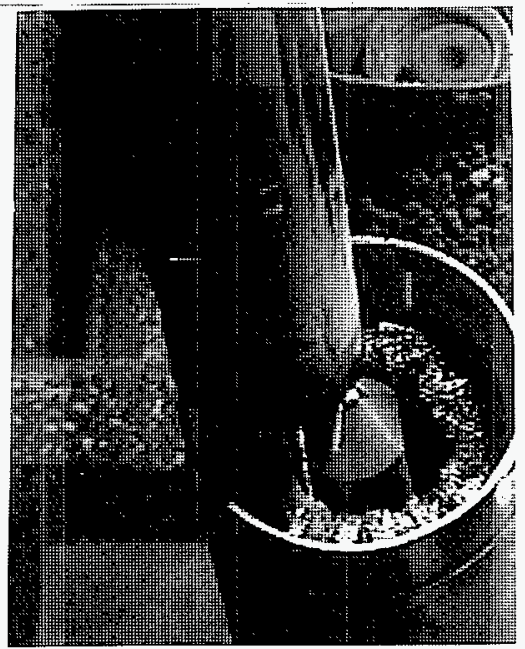

Before

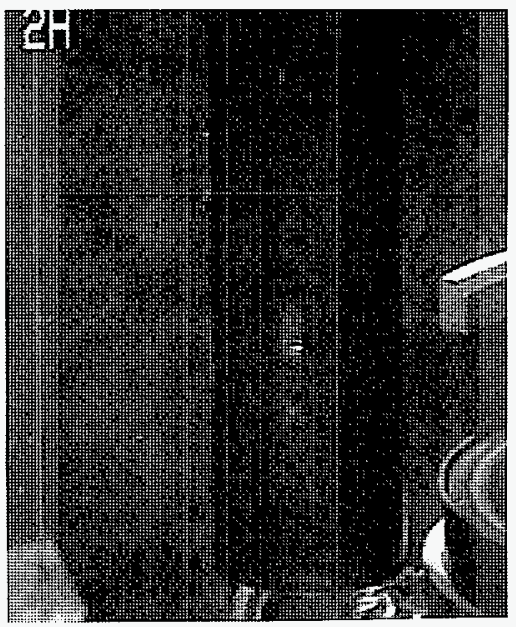

After

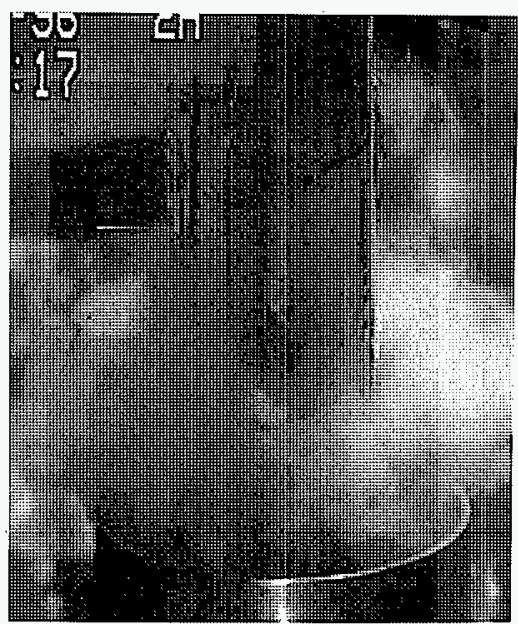

During

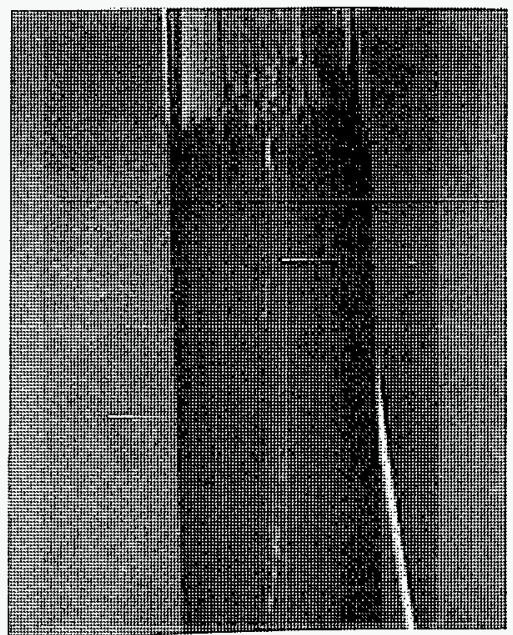

Transition Area 
Another difference between $K$ East fuel and $K$ West fuel, was the corrosion $\mathrm{KNO}_{2}$ inhibitor, that was added to the $K$ West canisters as part of the encapsulation process. There were many variables that were involved in hypothesizing the effects of the inhibitor on the fuel elements. For example, the amount of time the fuel was stored in N Reactor's Basin before encapsulation; the canisters may not of been injected with the same amount of inhibitor during encapsulation; and the canister could have leaked the inhibitor to the basin. The objective of this study was to analyze the adhesiveness of the sludge. The presence of inhibitor to the environment in 105-K West could have effected the adhesiveness of the sludge between 105-K West and 105-K East Basin. Plus, the inhibitor could have influenced the forming of sludge coatings during the encapsulation storage period. An example of this was the fifth element that was brushed, it had a very distinctive type of sludge that was only found in 105-K West. Although, the effects of the inhibitor are not exactly known, it does appear the inhibitor influenced the formation of this type of sludge. 
HNF-SD-SNF-TRP-020, Rev . 0

This page intentionally left blank. 


\subsection{CONCLUSION}

The brushing of the selected outer fuel elements from $105-K$ West demonstrated that most of the known coatings could be removed. The orange rust-like substance was more adhesive than most of the sludge coatings that were tested. This sludge coating needed more brushing strokes to remove it from the fuel element than the other types of sludge coatings (except the thick white sludge coating) that were tested. The fifth fuel element that was brushed had thick white streaks that could not be fully removed. This was the most adhesive type of sludge coating tested. The thick white sludge coating did show evidence that it could be removed if the testing continued for a longer duration. The rest of the sludge coatings tested were not as adhesive and were easily removed by the FEBA. The inhibitor added to the 105-K West canisters may have changed the adhesiveness of the sludge when compared to the adhesiveness of sludge from 105-K East. The last point is that the sludge covered some of the cracks on some of the outer fuel elements. This suggests characterized unbrushed fuel elements could have more damage than they appeared in the visual examinations of $K$ West fuel elements. In conclusion, this testing demonstrated that the sludge can be removed from fuel elements, but it takes more effort to remove certain types of sludge coatings such as the thick white sludge found on the fifth element brushed. These tests pointed out that the sludge does not come off as a result of moving the fuel in the water. 
HNF-SD-SNF-TRP-020, Rev . 0

This page intentionally left blank. 


\subsection{REFERENCES}

Bergmann, D. W., and W. A. Briggs, 1996, Sludge Adherence Summary Report" WHC-SD-SNF-TRP-015, Rev. 0, Westinghouse Hanford Company, Richland, Washington.

Lawrence, L. A., B. J. Makenas, and D. W. Bergmann, 1997, Data Quality objectives for the Second $K$ West Fuel Examinations" HNF-SD-SNF-DQ0-011, Rev. 0, Duke Engineering \& Services Hanford, Inc., Richland, Washington.

Makenas, B. J., L. A. Lawrence, and A. L. Pitner, 1997, Internal Memo, "Recommended $K$ West Bas in Canisters For Fuel Element Retrieval (Second Campaign)," Duke Engineering \& Services Hanford, Inc., Richland, Washington.

Pitner, A. L., 1997, Visual Examinations of $K$ West Fuel Elements, HNF-SD-SNF-TI-046, Rev. 0, Duke Engineering \& Services Hanford, Inc., Richland, Washington.

Short, S. M., and M. M. Beary, 1995, Spent Nuclear Fuel Project Technical Databook, WHC-SD-CP-TI-015, Rev. 0, Westinghouse Hanford Company, Richland, Washington. 
HNF-SD-SNF-TRP-020, Rev. 0

This page intentionally left blank. 


\section{A P PEN D I X A}

\section{SUPPORTING DOCUMENT (INTERNAL MEMORANDUM)}

The internal memorandum, "Recommended $K$ West Basin Canisters for fuel Element Retrieval (Second Campaign), "included in this appendix, shows the canister barrels containing fuel elements that were selected for brushing from a list of fuel elements to be retrieved. None of the retrieved fuel elements were brushed. only the outer fuel elements in the same barrel as the fuel element, retrieved for laboratory examinations, were candidates to be brushed. All of the canister barrels that contained primary brushing candidates had at least one outer fuel element brushed, but any outer element in a barrel that was on the list for fuel retrieval could also have been brushed. The only outer fuel element brushed that was not on the primary list, but on the fuel retrieval 1 ist, was from the unmarked barrel of canister 1164 . 
HNF-SD-SNF-TRP-020, $\begin{array}{r}\text { Rev. } \\ \text { Page } 40\end{array}$

This page intentionally left blank. 
DE\&S Hanford, Inc.

From: $\quad$ Spent Nuclear Fuel Evaluations

Phone: $\quad 376-5447$ HO-40

Date: January 15,1997

Subject: RECOMMENDED $K$ WEST BASIN CANISTERS FOR FUEL ELEMENT RETRIEVAL (SECOND CAMPAIGN)

To: R. P. Omberg HO-40

cc: Distribution

Reference: L. A. Lawrence, B. J. Makenas, and D. W. Bergmann, "Data Quality Objectives for the Second $K$ West Fuel Examinations," HNF-SD-SNF-DQO-011, Rev. O, dated January 1997.

The 15 elements listed in Table 1 are recommended to be shipped from $K$ West Basin to 327 Building hot cells for examination. These elements will satisfy the requirements specified in the reference. Elements representing categories such as top and/or bottom failures, severe damage, mid-element cracks, complete break, and unusual coatings have been included. These will feed whole-element drying, thermogravimetric analyses, coating scraping, and visual examinations.

Also specified in Table 1 are number of backup choices in case difficulties are encountered during canister or element handling. Top view pictures of each candidate canister (as seen during the recent visual examination campaign) are attached to aid in element identification.

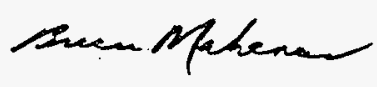

B. J. Makenas

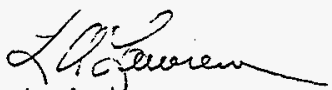

L. A. Lawrence

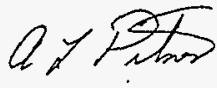

A. L. Pitner

jmn

Attachment

CONCURRENCE:
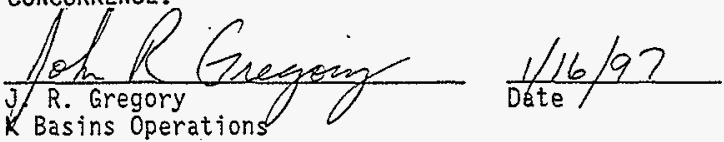


\author{
ATTACHMENT \\ List and Photographs of Candidate Canisters \\ Consisting of 22 pages, \\ including cover page
}


Table 1. FueT Elements to be Shipped to Hot Cells for the Second $K$ West Basin Fuel Retrieval Campaign.

\begin{tabular}{|c|c|c|c|c|c|c|}
\hline $\begin{array}{c}\text { Canister } \\
\text { Number }\end{array}$ & Location & $\begin{array}{l}\text { Element } \\
\text { Number }\end{array}$ & $\begin{array}{c}\text { Canister } \\
\text { Type }\end{array}$ & Requirement ${ }^{2}$ & $\begin{array}{l}\text { Fuel } \\
\text { Type } \\
\end{array}$ & $\begin{array}{c}\text { Fuel } \\
\text { Model } \\
\text { Code }\end{array}$ \\
\hline \multicolumn{7}{|c|}{ Prime Candidates } \\
\hline $161 M^{3}$ & 2913 & 2 & MK 1 & Coating & MK IA & AM \\
\hline $2667 U^{3}$ & 2923 & 3 & MK I & Coating & MK IA & AM \\
\hline $5744 U$ & 4511 & 4 & MK II & Broken top end & MK IA & AM \\
\hline $6743 M$ & 3740 & 6 & MK II & Broken top end & MK IA & AM \\
\hline $6603 M$ & 5652 & 5 & MK II & Broken bottom end & MK IV & $\mathrm{BE}$ \\
\hline $7913 M$ & 3545 & 6 & MK II & Broken bottom end & MK IA & AM \\
\hline 67430 & 3740 & 6 & MK II & Cladding peal & MK IA & AM \\
\hline 79130 & 3545 & 4 & MK II & Cladding peal & MK IA & AM \\
\hline $1164 M$ & 3619 & 5 & MK I & Mid-element cracks & MK IA & AM \\
\hline $6743 \mathrm{U}$ & 3740 & 2 & MK II & Mid-element cracks & MK IA & $A M$ \\
\hline $1164 U$ & 3619 & 1 & MK I & Mid-element cracks & MK IA & AM \\
\hline $2660 \mathrm{M}$ & 1630 & 6 & $M K-1$ & Severely damaged & MK IA & AM \\
\hline $6513 U$ & 4557 & 6 & MK II & Severely damaged & MK IA & AM \\
\hline $6513 M$ & 4557 & 1 & MK II & Severely damaged & MK IA & AM \\
\hline $0309 \mathrm{M}^{4}$ & 5370 & 6 & MK I & Broken in half & MK IV & $B E$ \\
\hline \multicolumn{7}{|c|}{ Backup Candidates } \\
\hline $1497 M^{3}$ & 3839 & 4 & $M K I$ & $\begin{array}{l}\text { Backup coating with top } \\
\text { rupture }\end{array}$ & MK IA & AM or \\
\hline $5744 M^{3}$ & 4511 & 6 & MK II & $\begin{array}{l}\text { Backup coating with top } \\
\text { and bottom rupture }\end{array}$ & MK IA & AM \\
\hline 79130 & 3545 & 5 & MK II & Backup broken bottom & MK IA & AM \\
\hline $1164 \mathrm{M}$ & 3619 & 2 & MK I & $\begin{array}{l}\text { Backup top and bottom } \\
\text { rupture }\end{array}$ & MK IA & $A M$ \\
\hline $0309 u^{4}$ & 5370 & 6 & MK I & Backup clean break & MK IV & $B E$ \\
\hline
\end{tabular}

${ }^{1} \mathrm{CW}$ from trunion with element closest to trunion designated as Number 1.

${ }^{2}$ Backup elements with coincident top and bottom ruptures may be substituted

for cladding peal, top or bottom rupture, mid-element cracking, or severely damaged categories.

${ }^{3}$ Canisters containing primary elements for brushing.

"Formerly canister 1560 prior to 7 id replacement. 


\section{$0161 M-N o .2$}
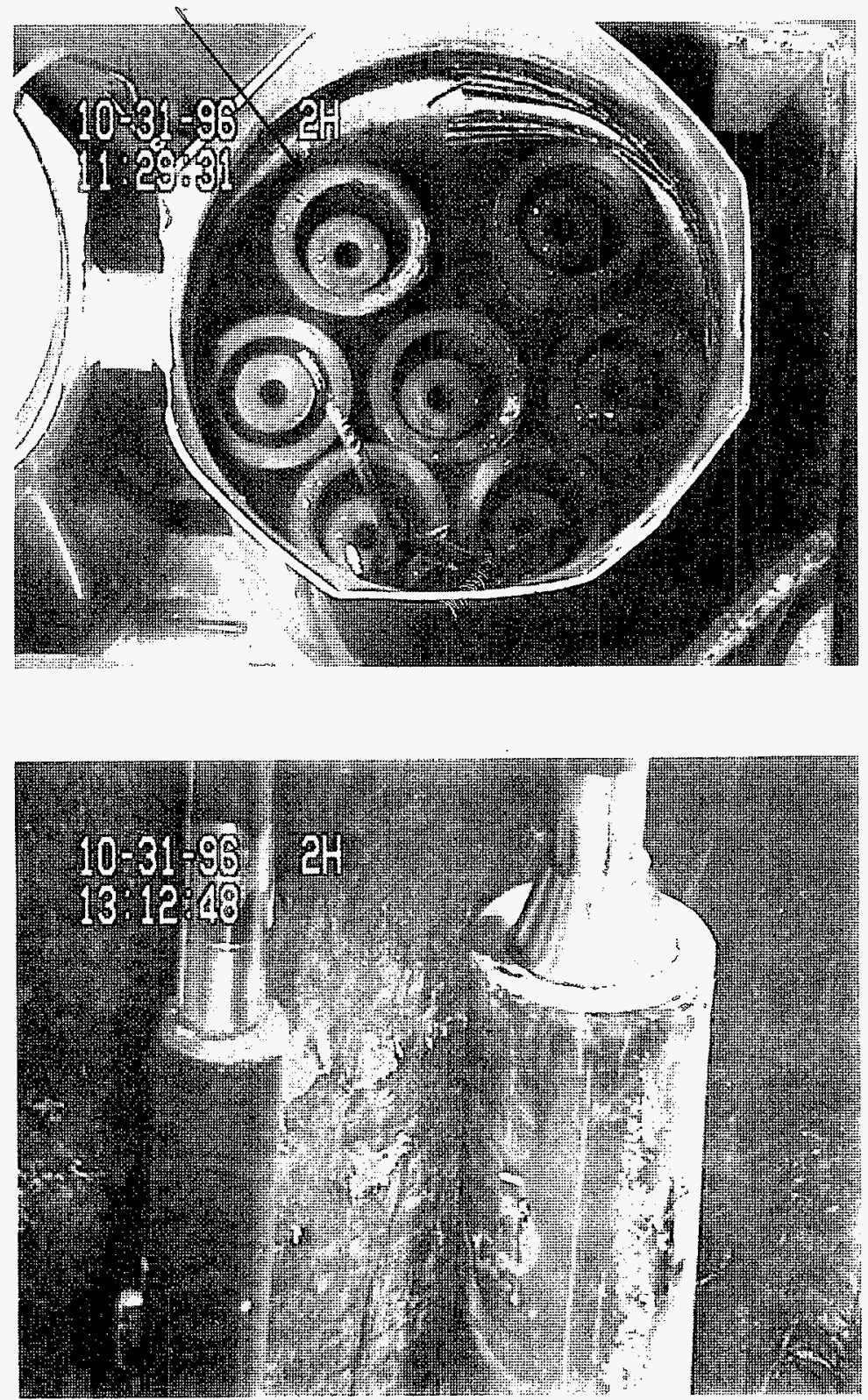


\section{7 -No. 3}

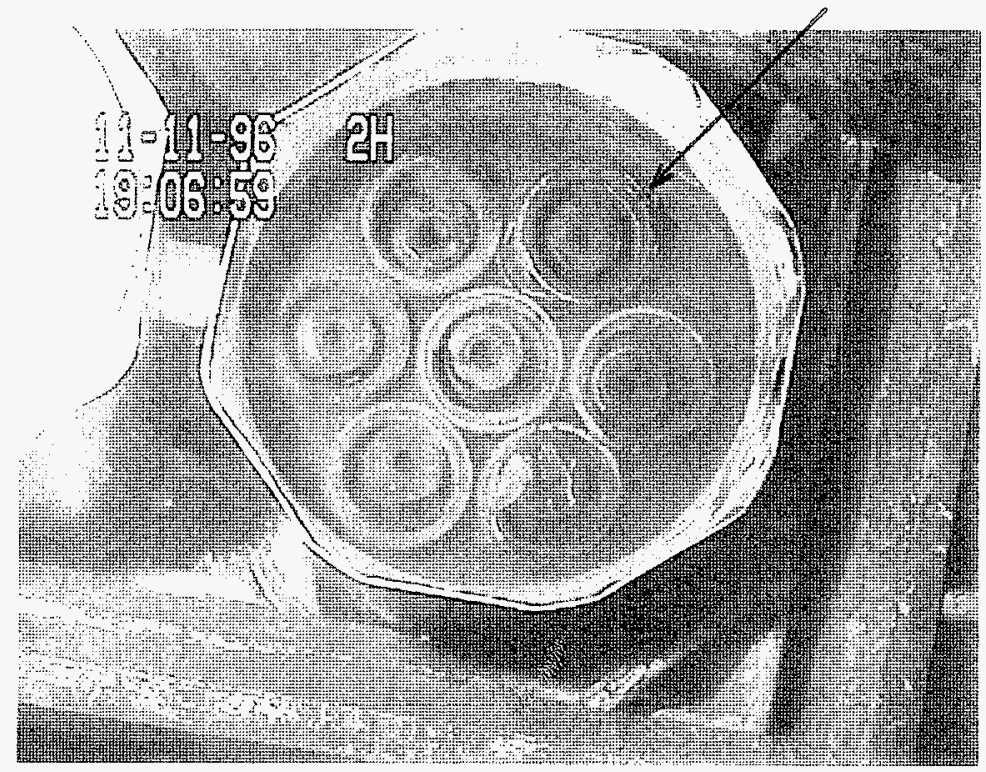

Page 45

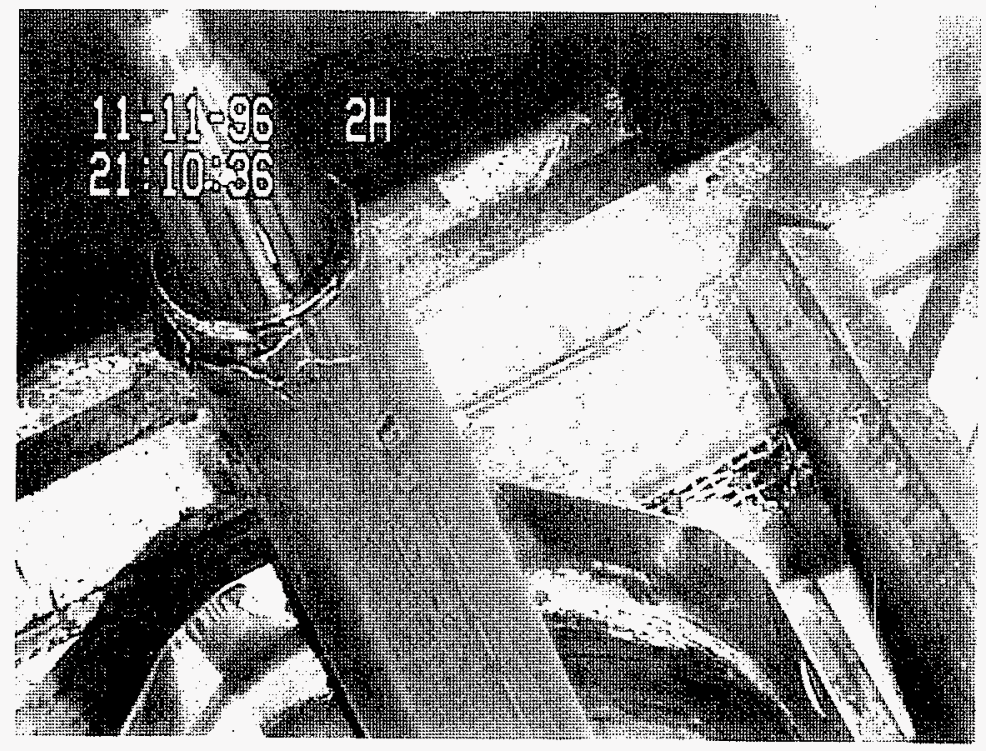



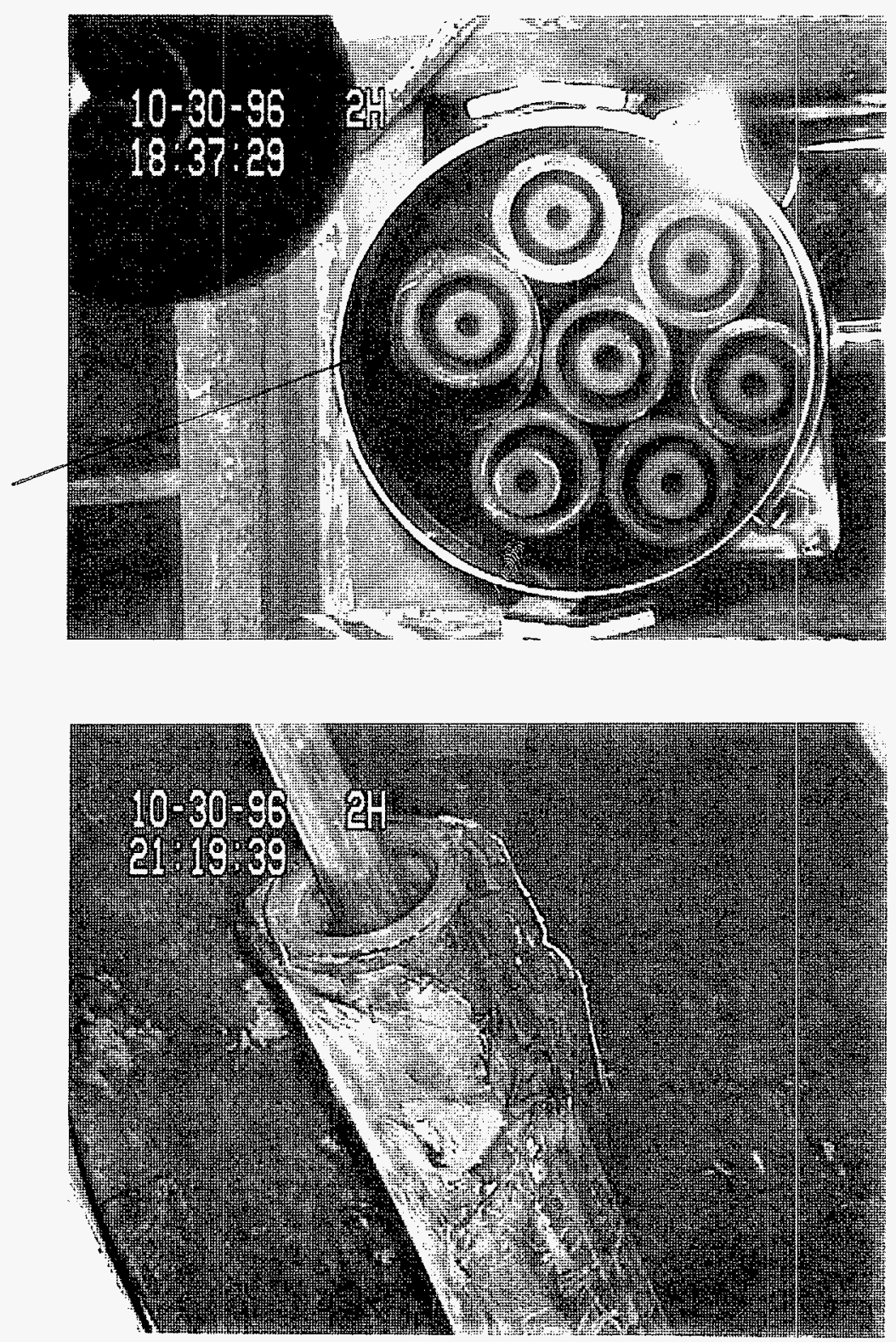

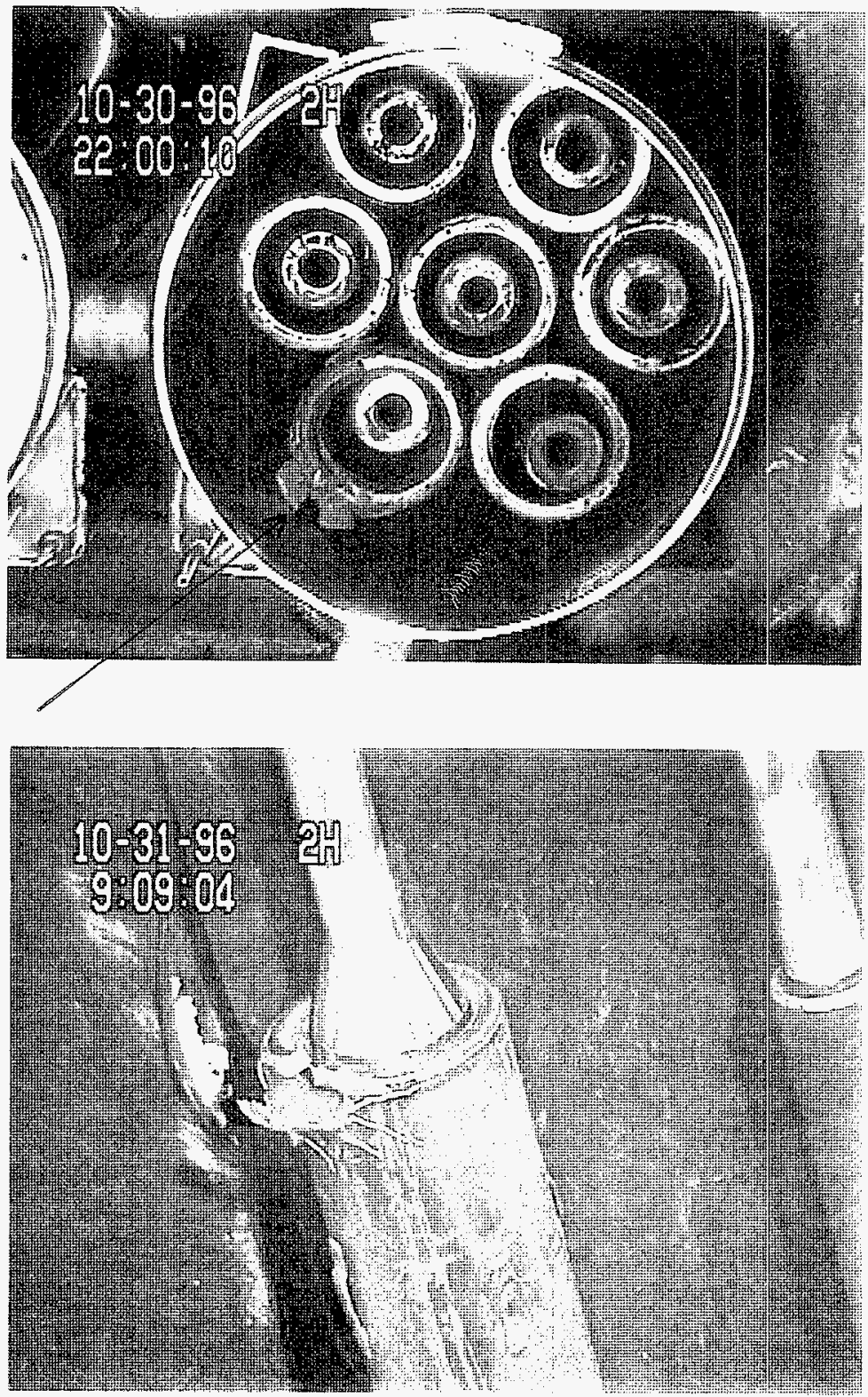

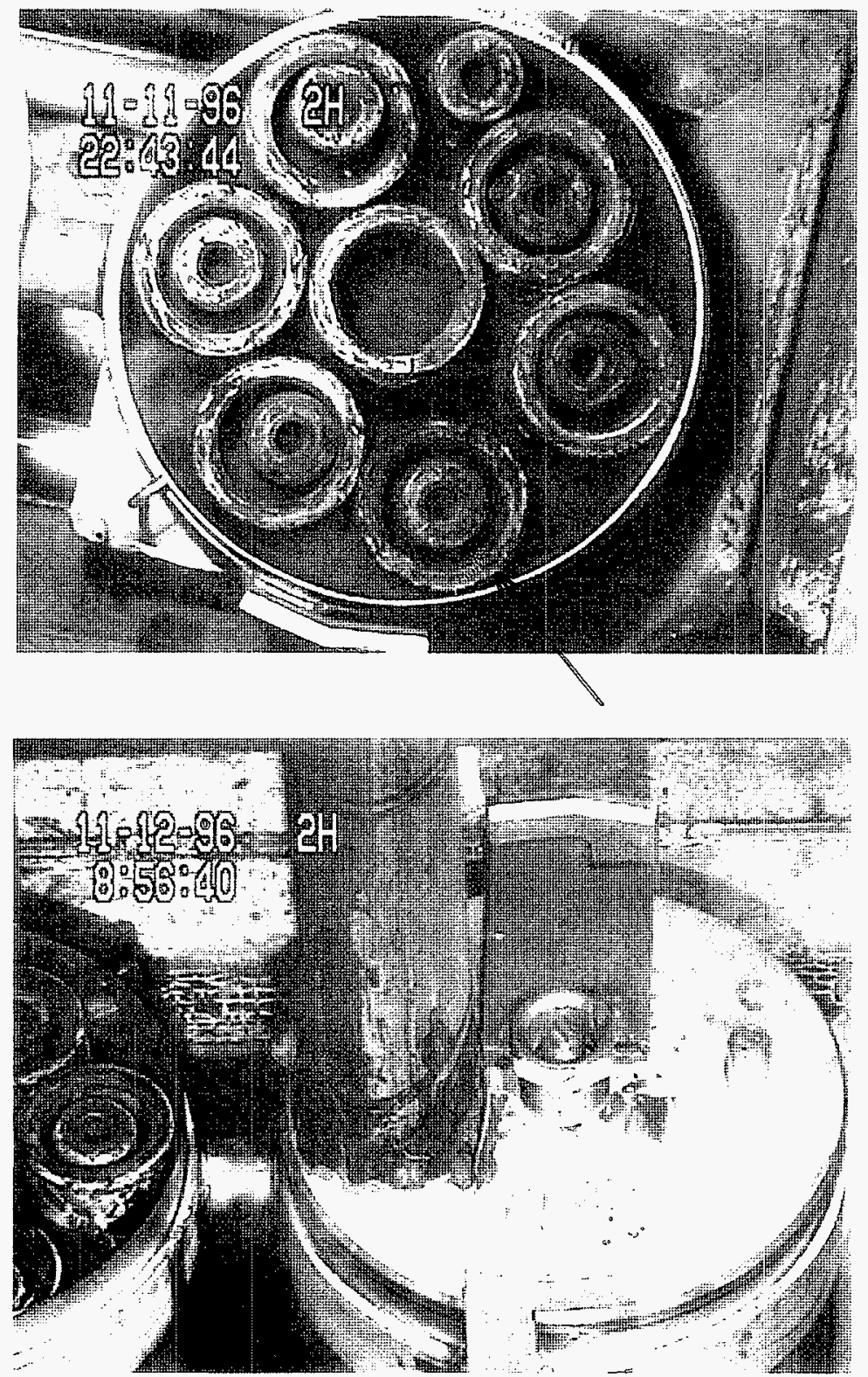


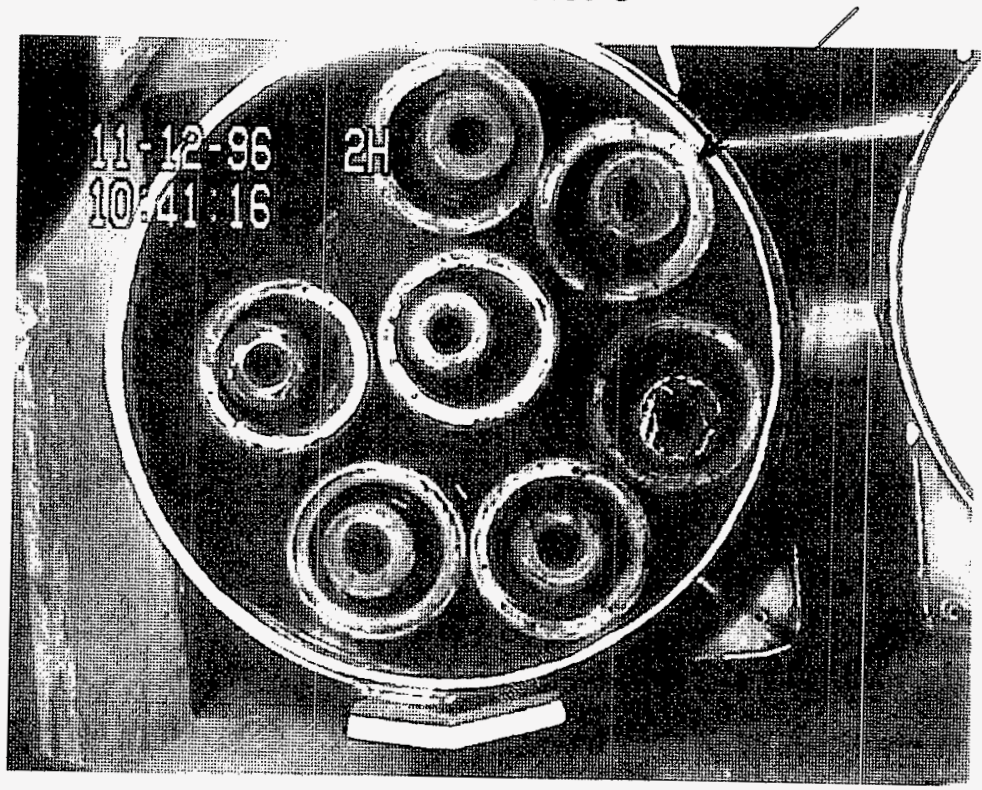

Page 49

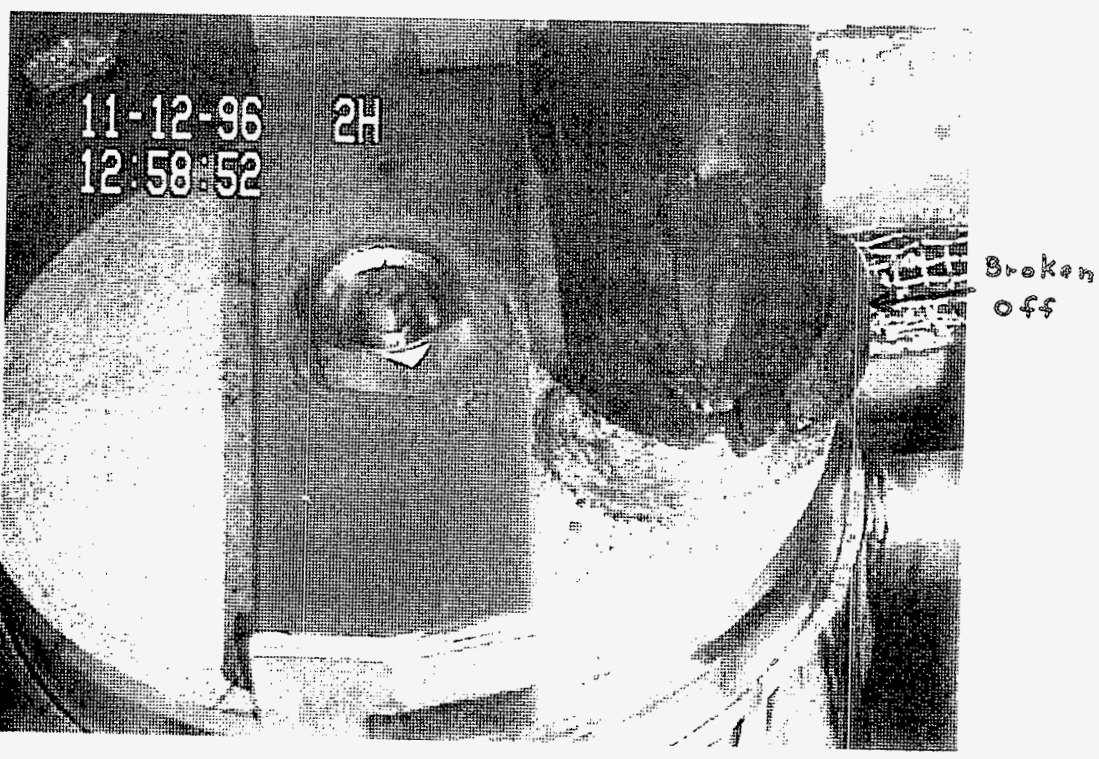



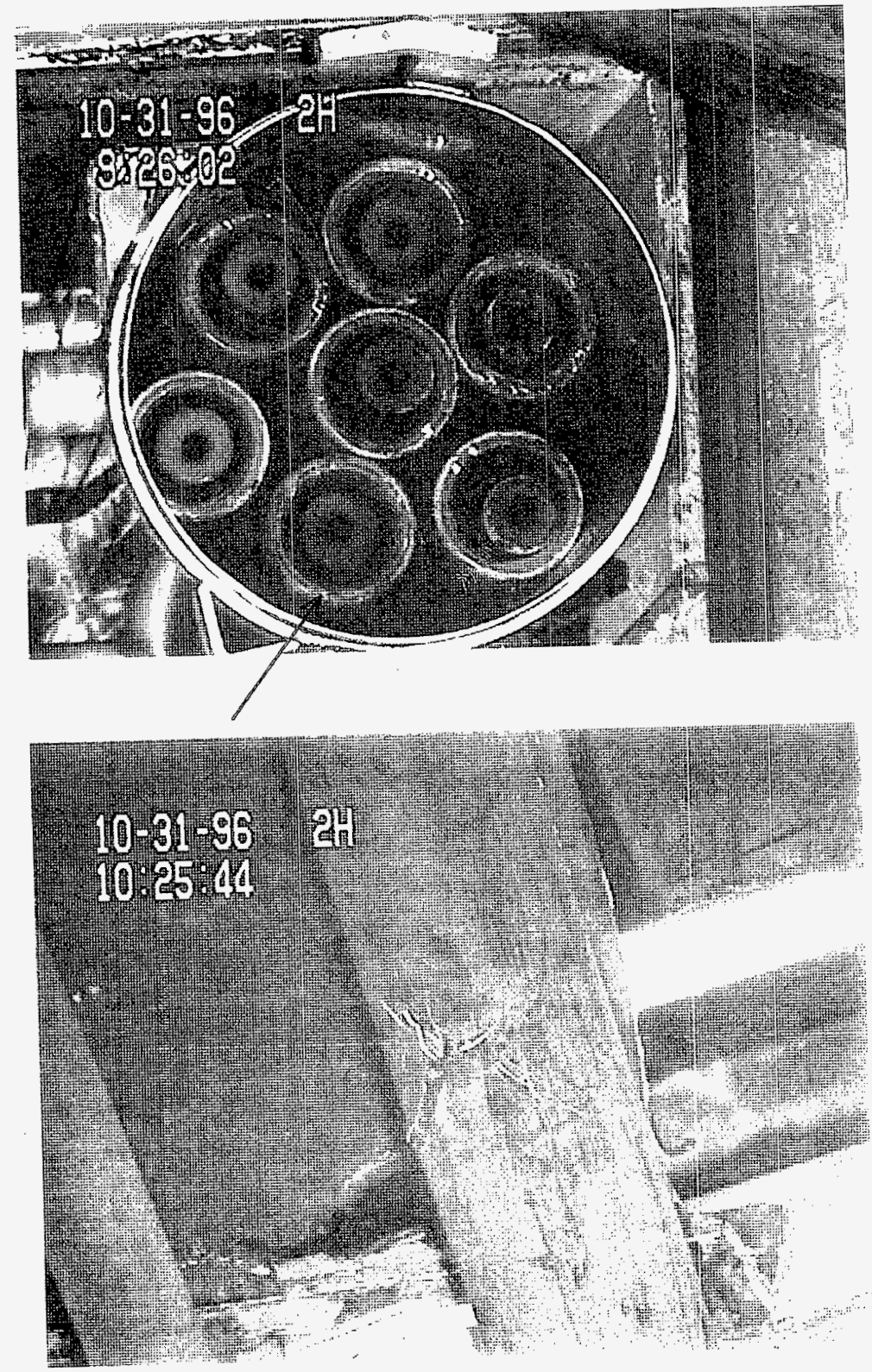


\section{$7913 \cup \ldots$ No. 4}
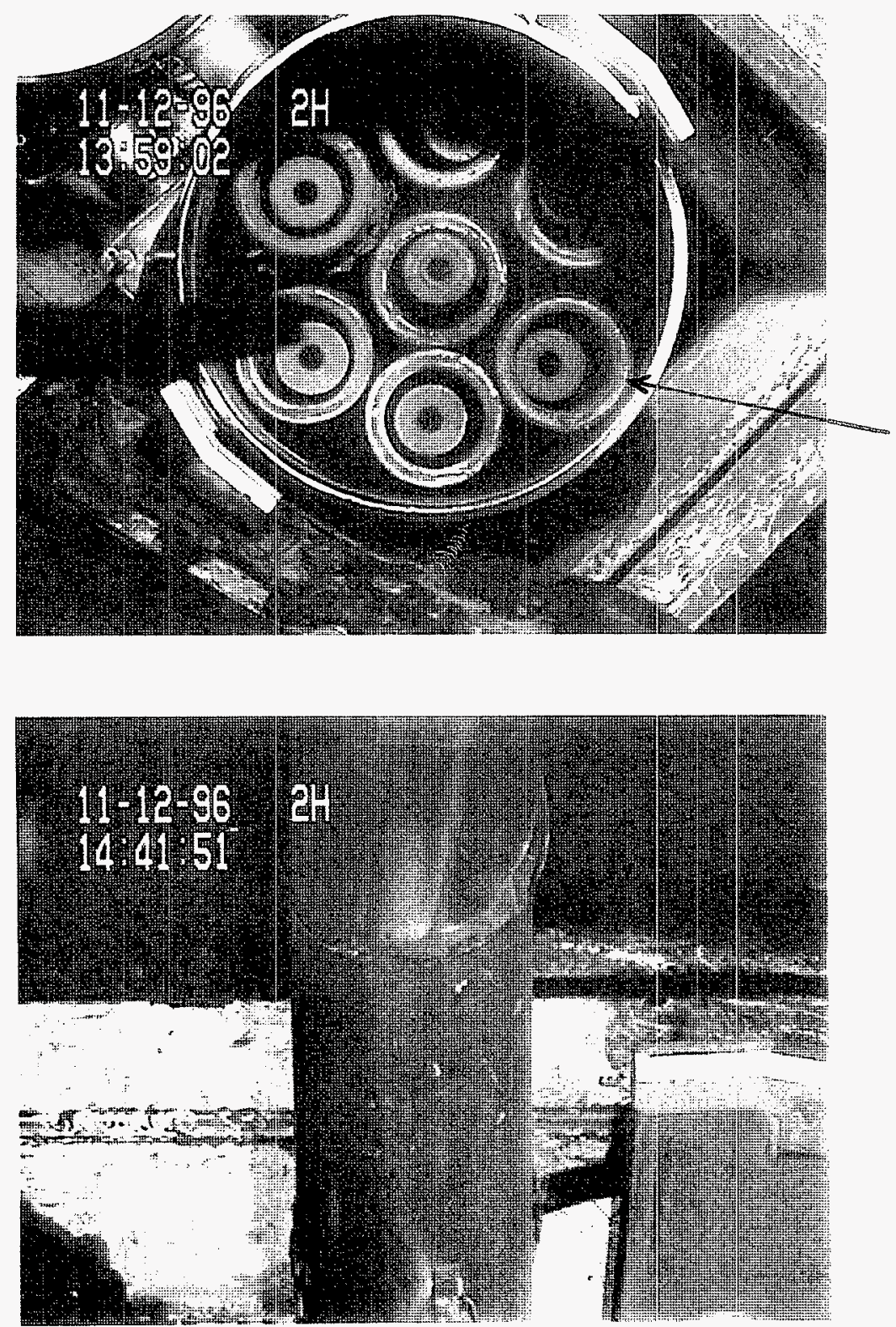

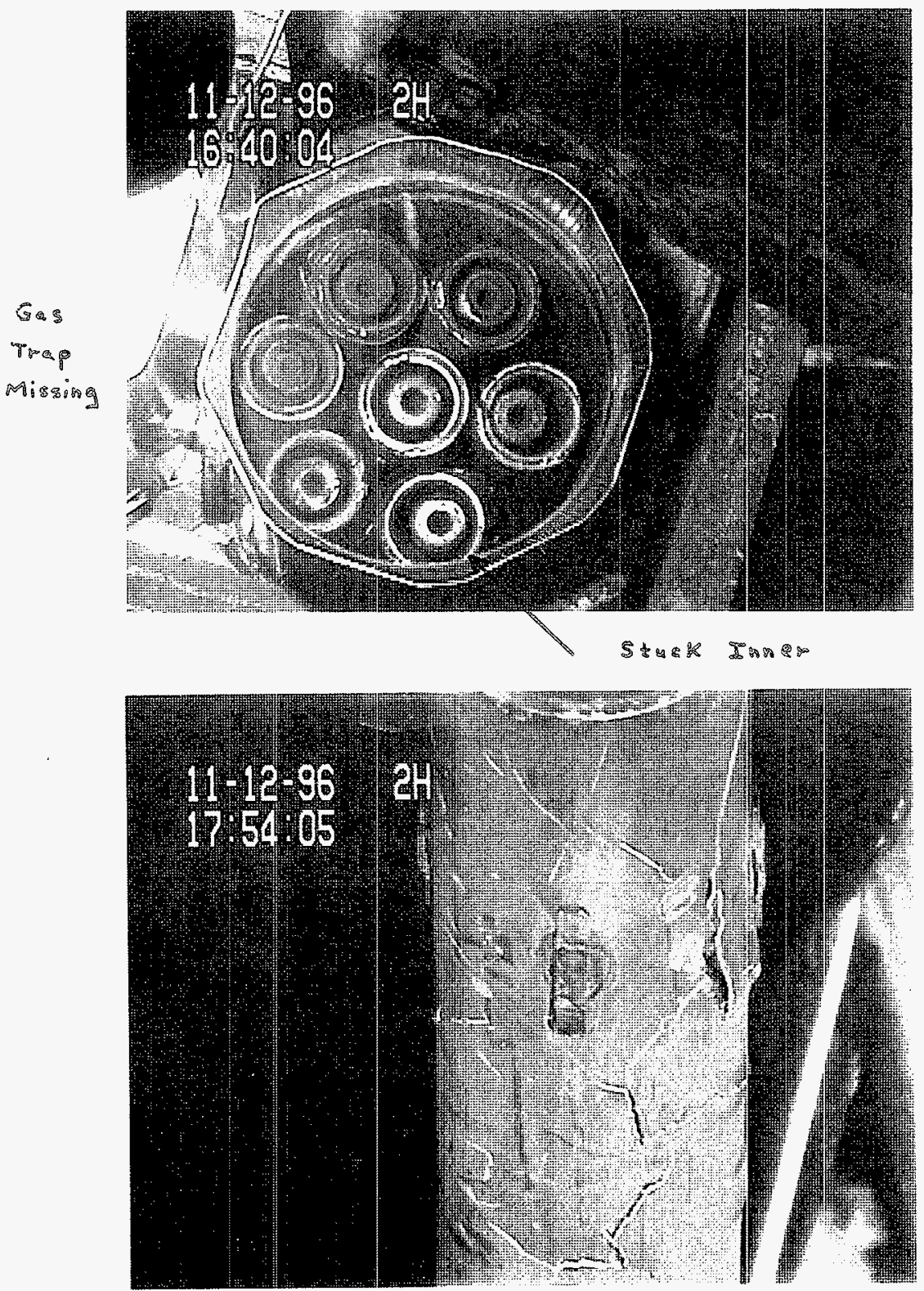


\section{$6743 \cup$-. No. 2}
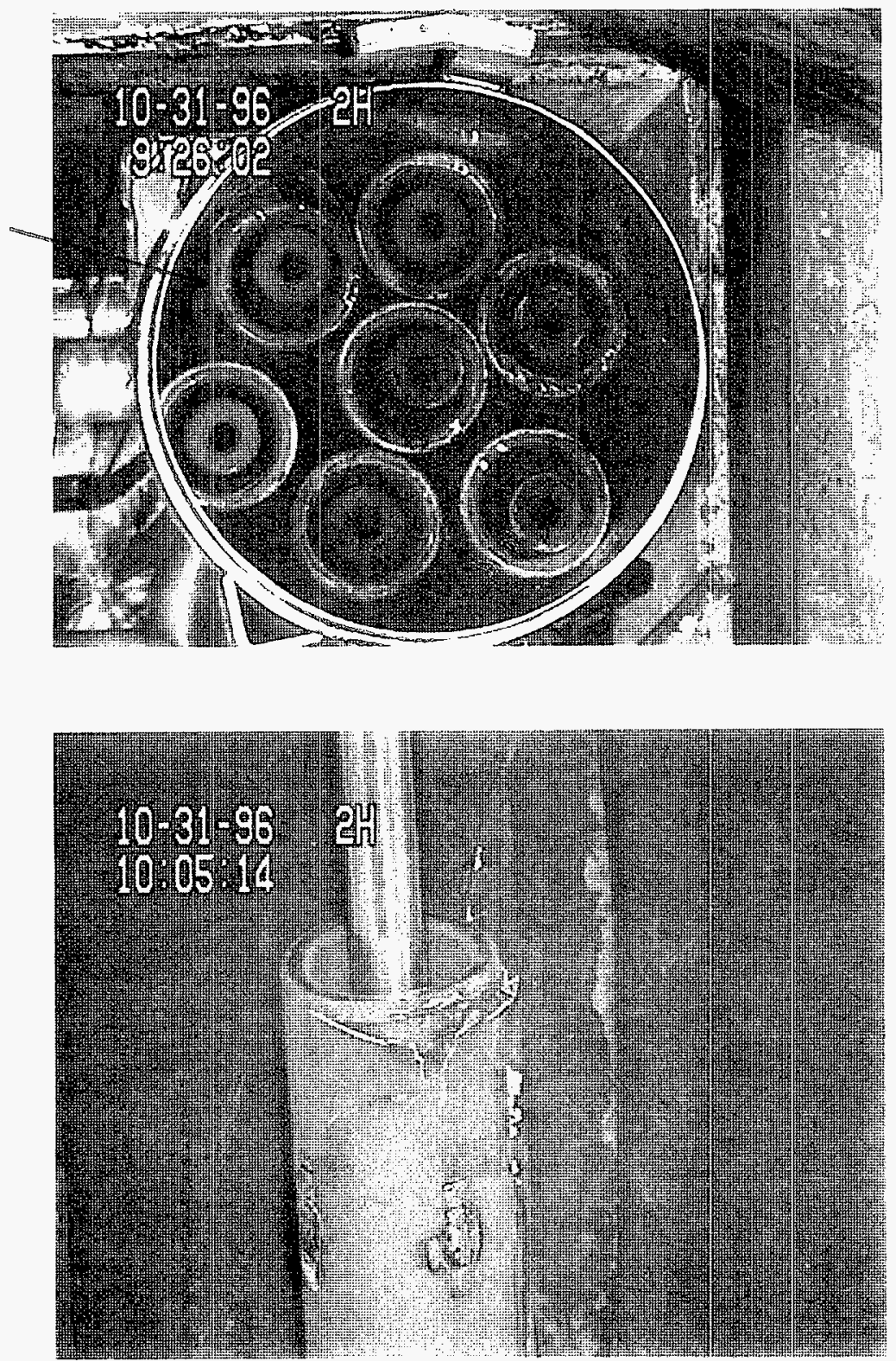


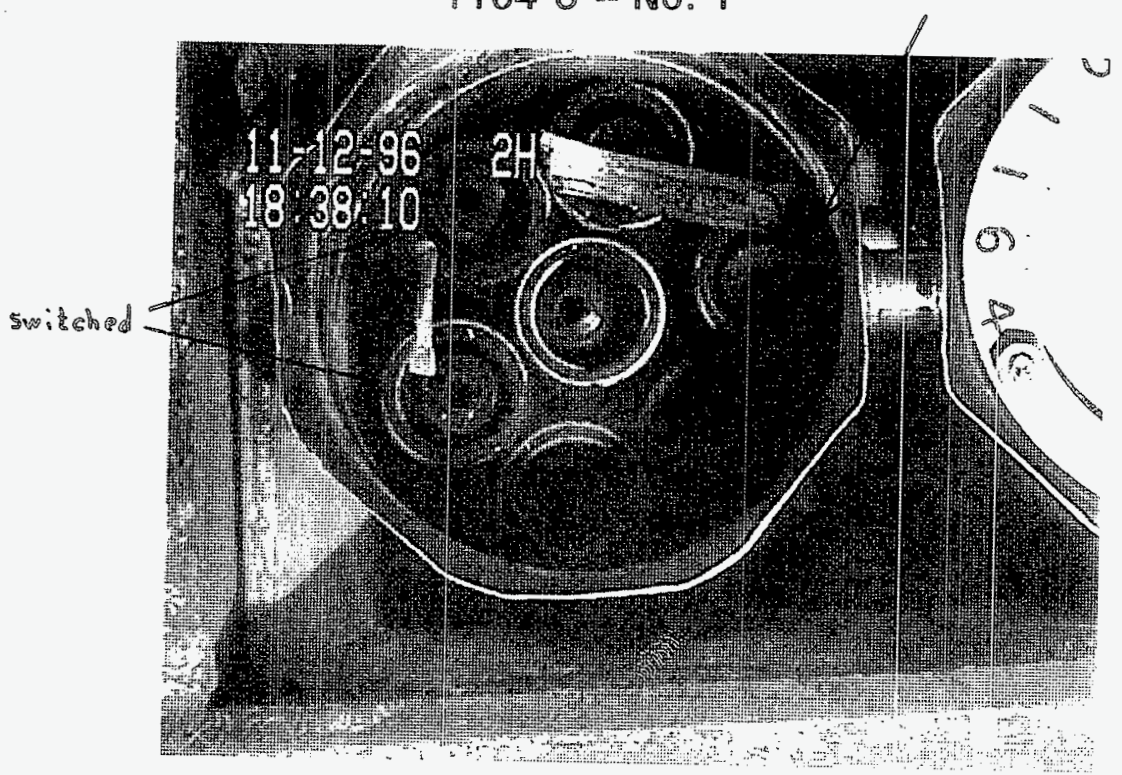

Page 54

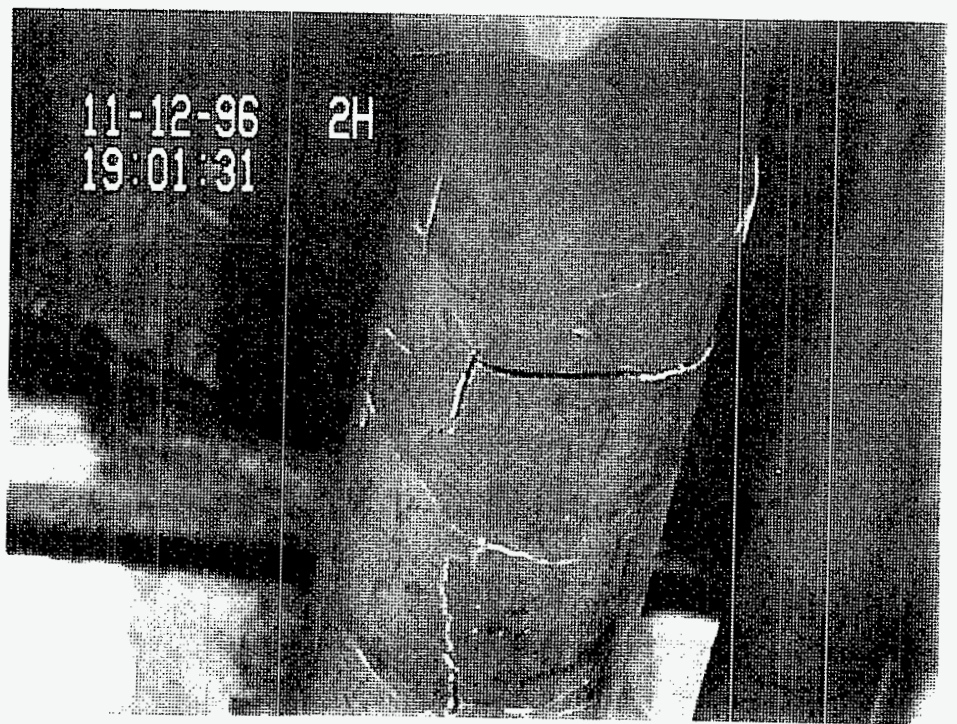



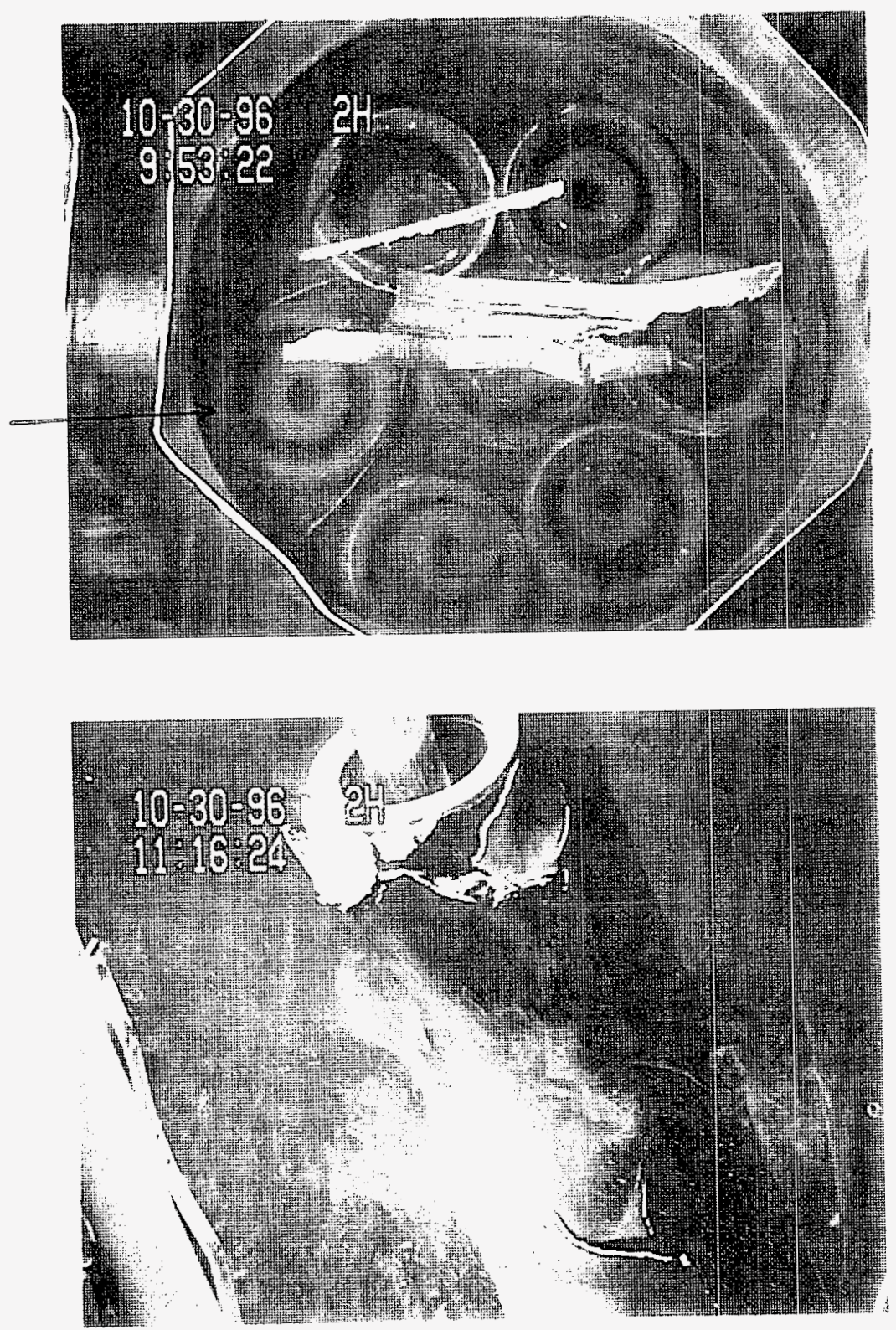

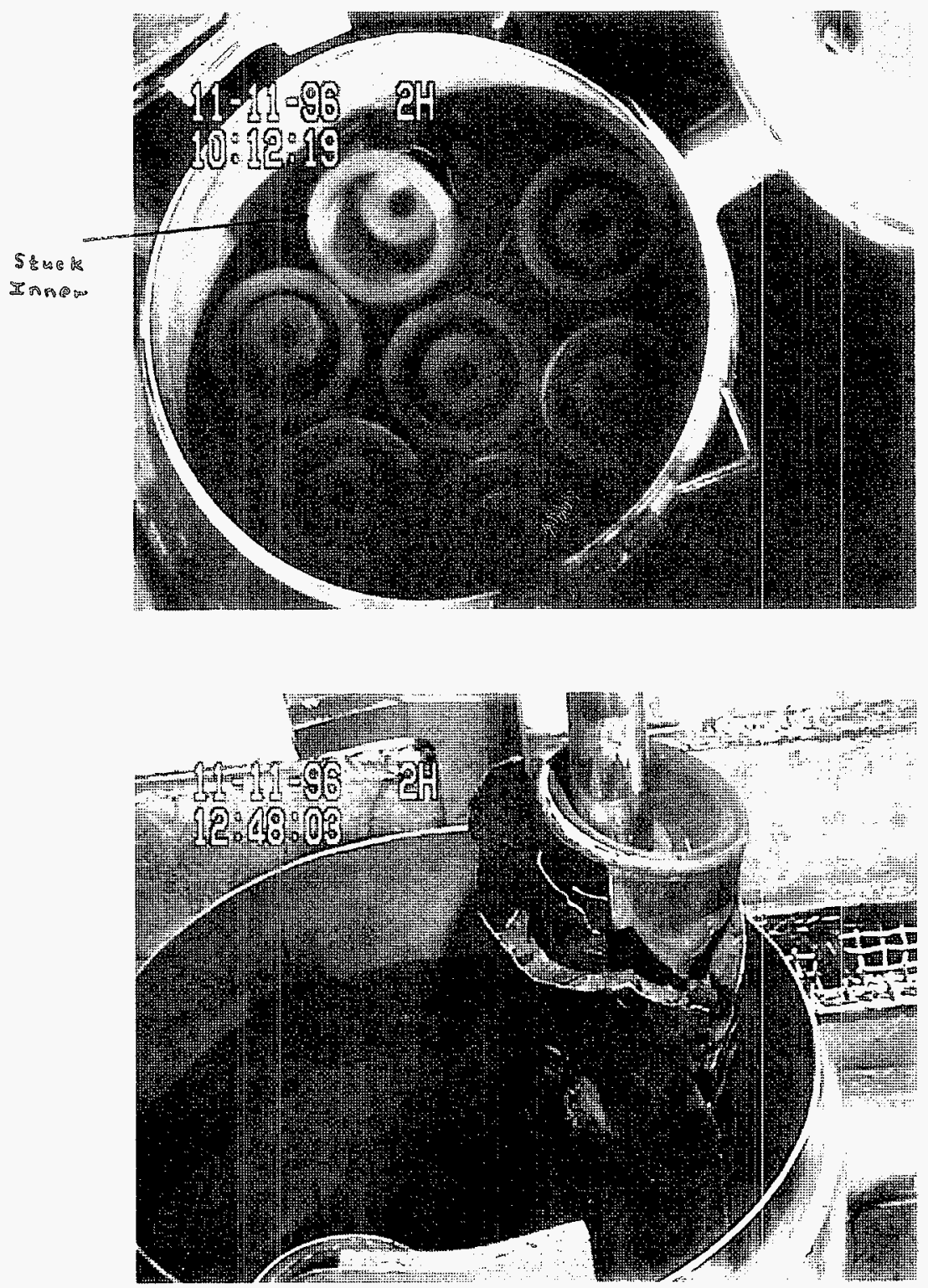

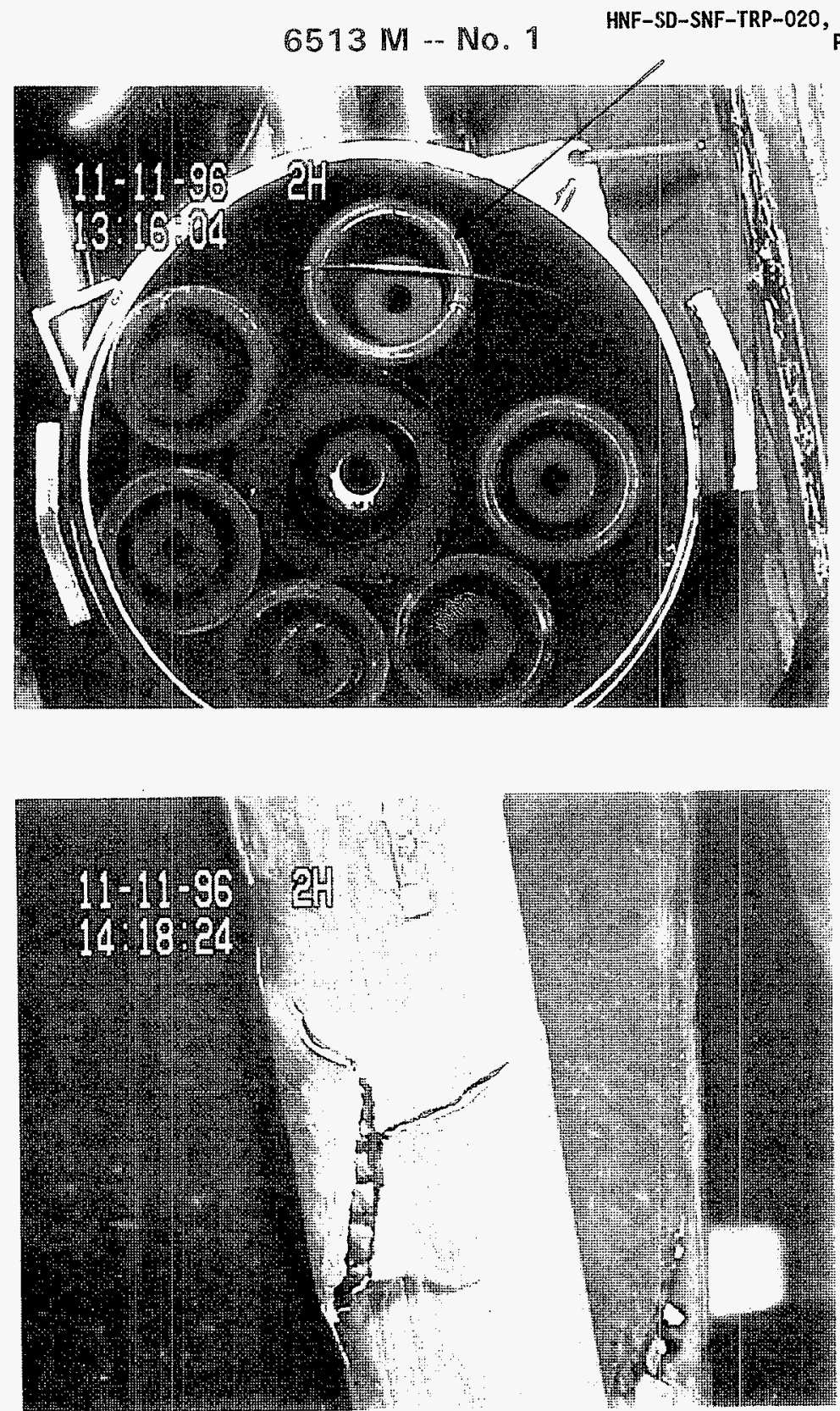

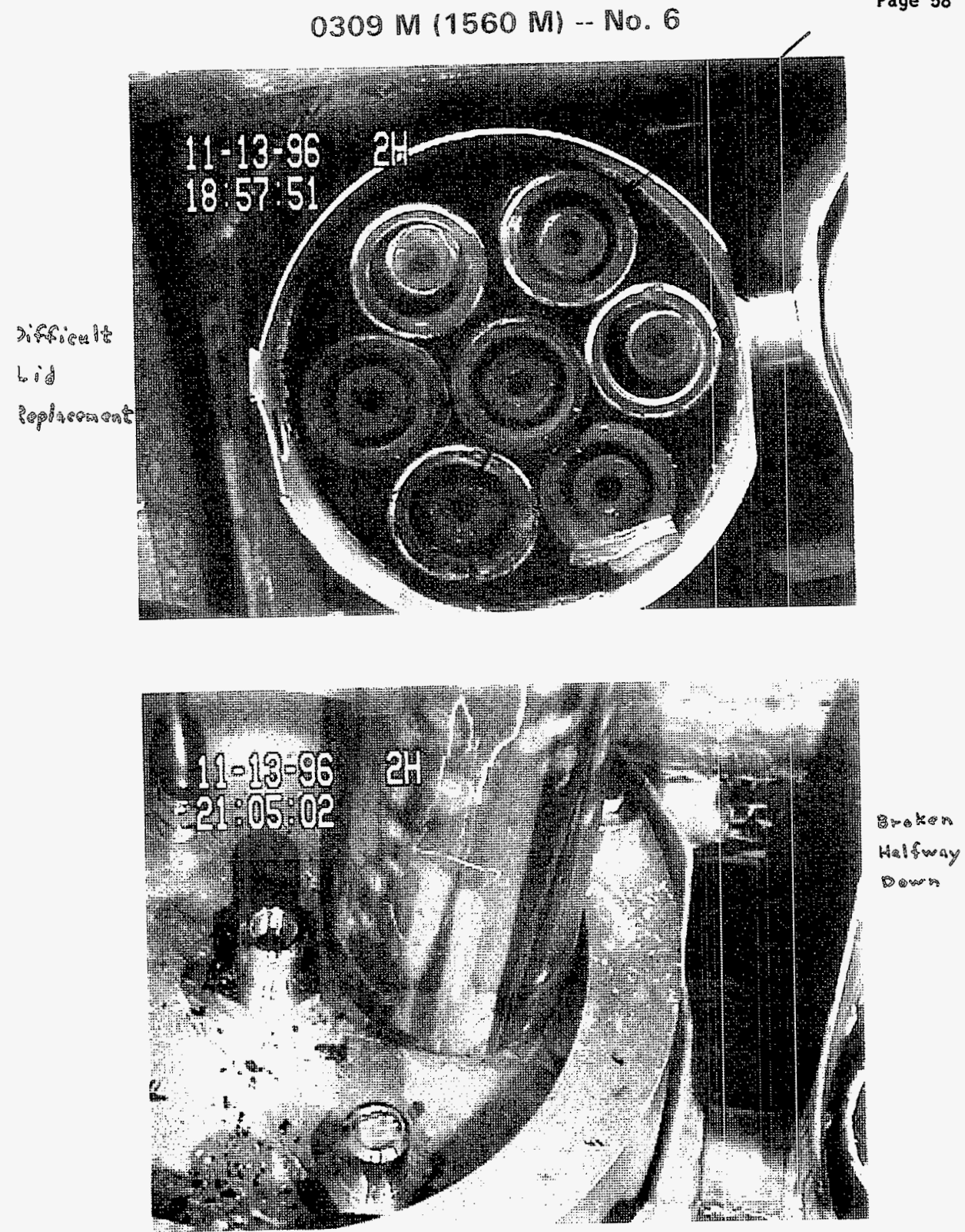


\section{M NO. 4}
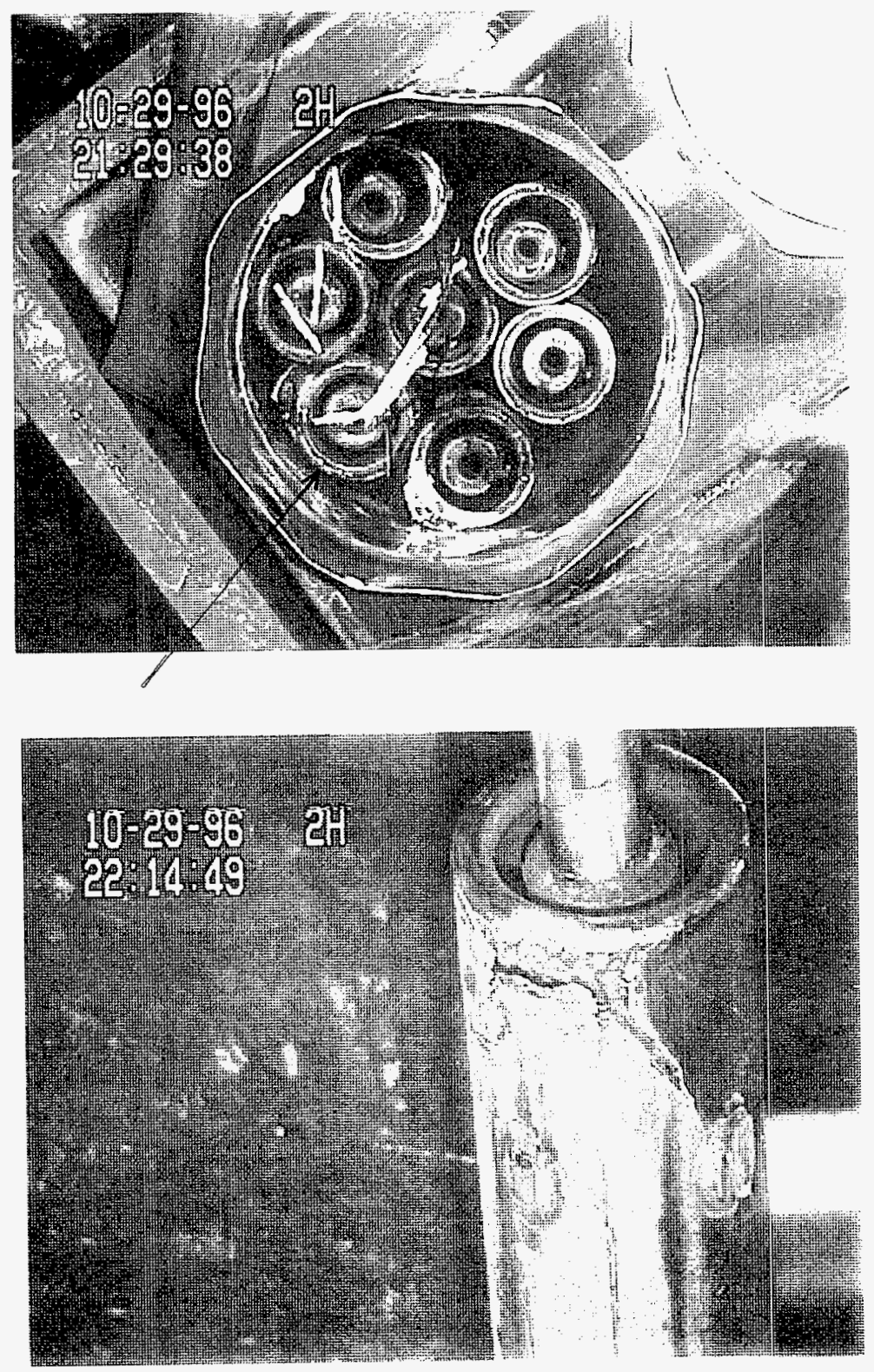

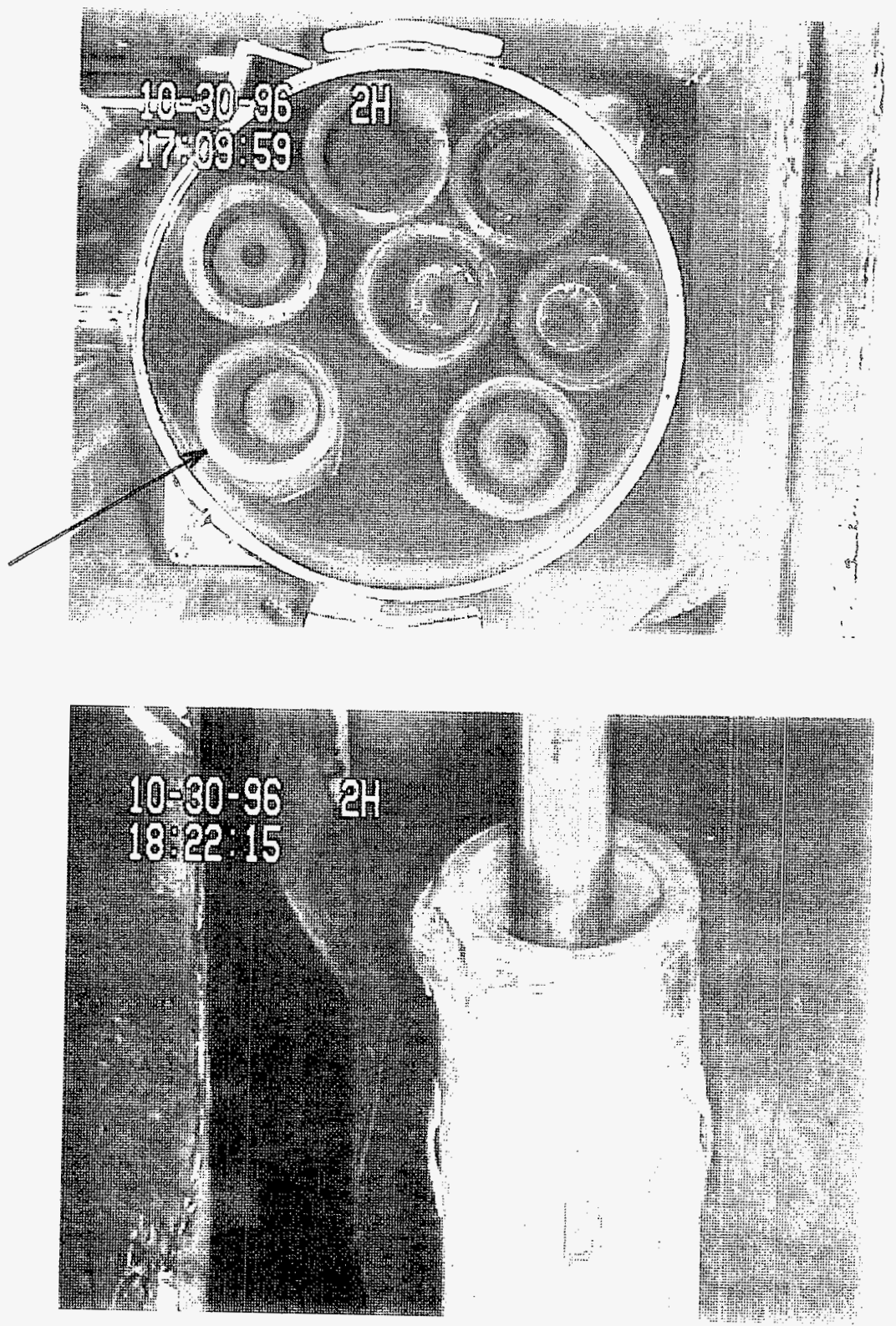

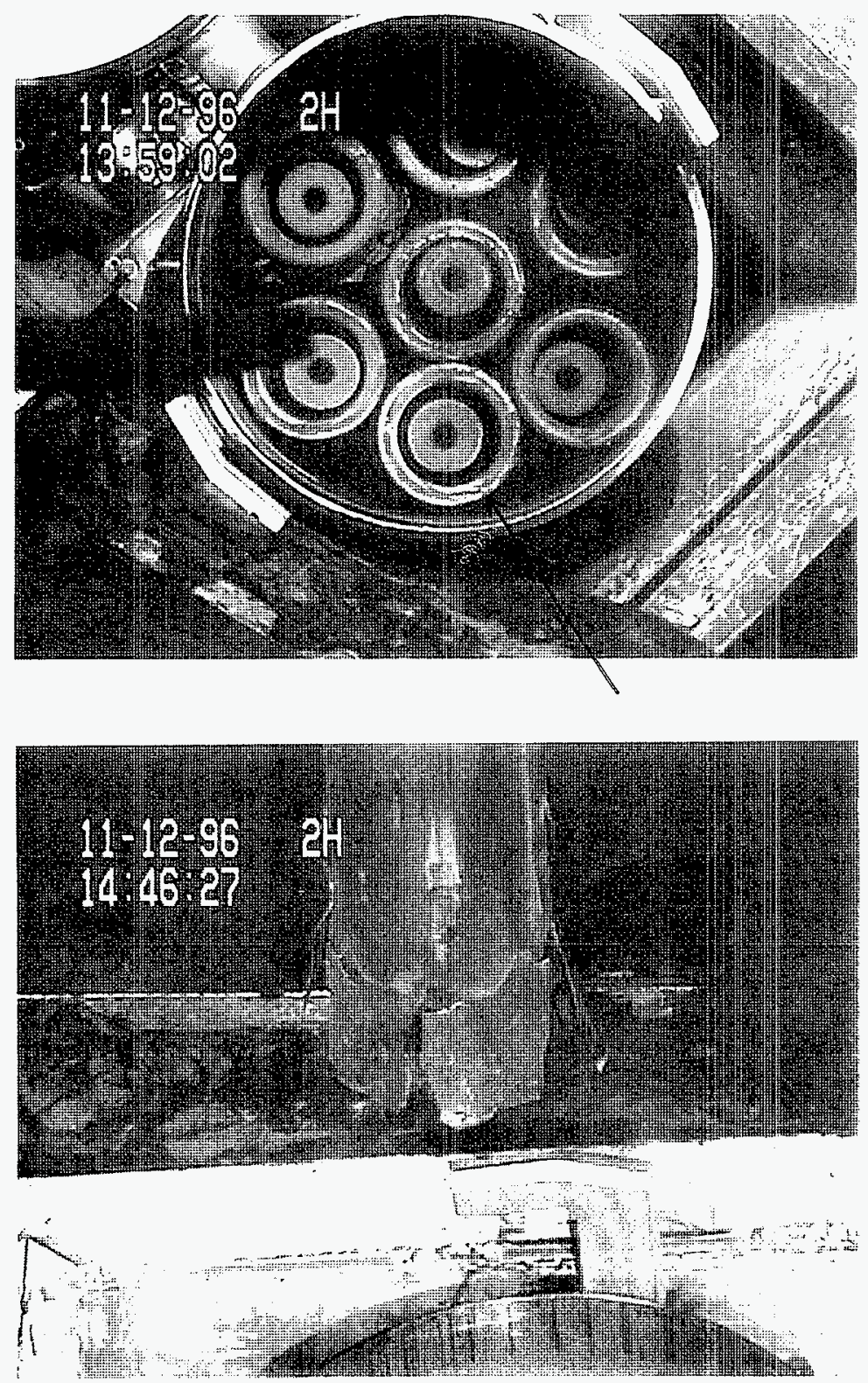

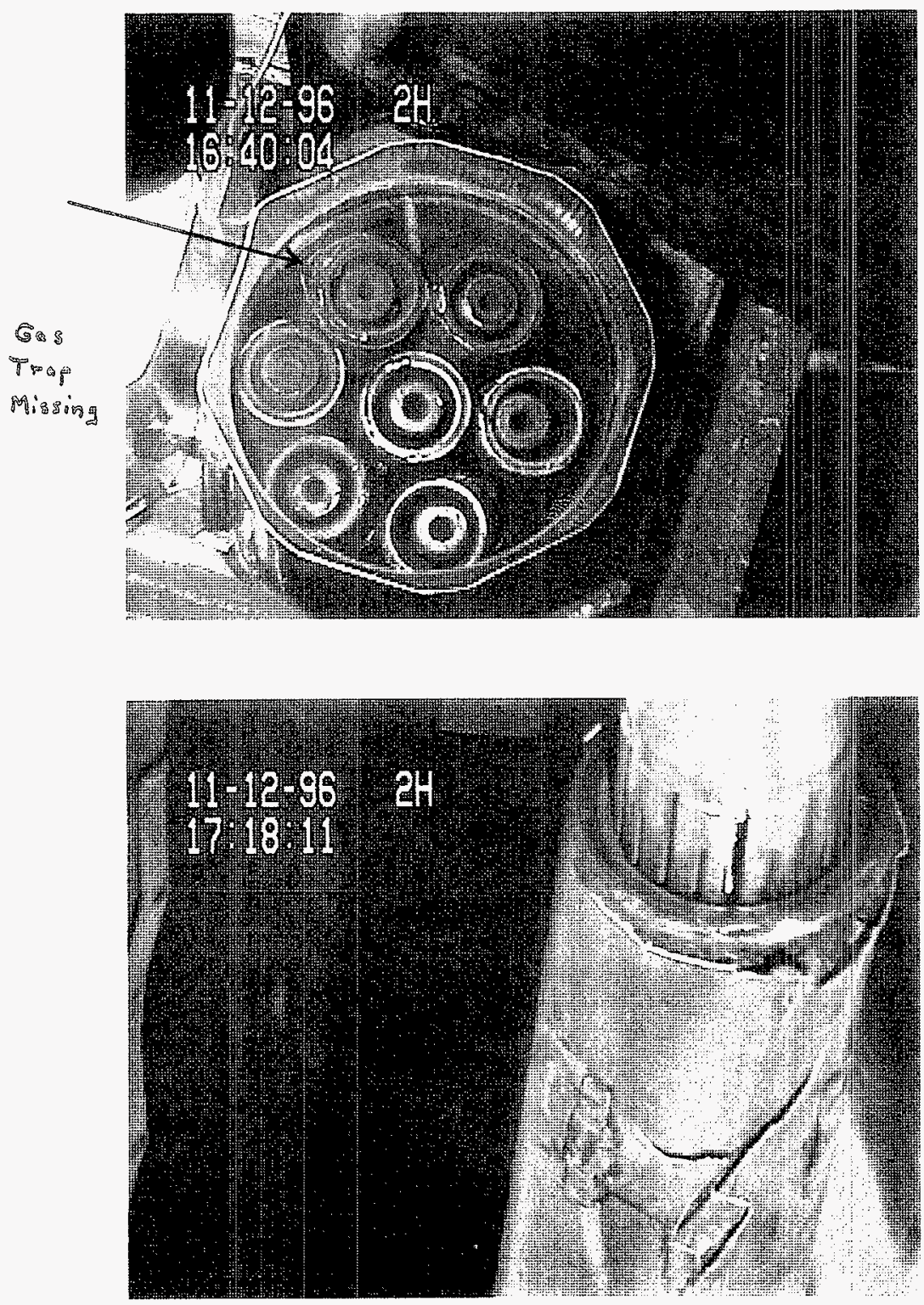

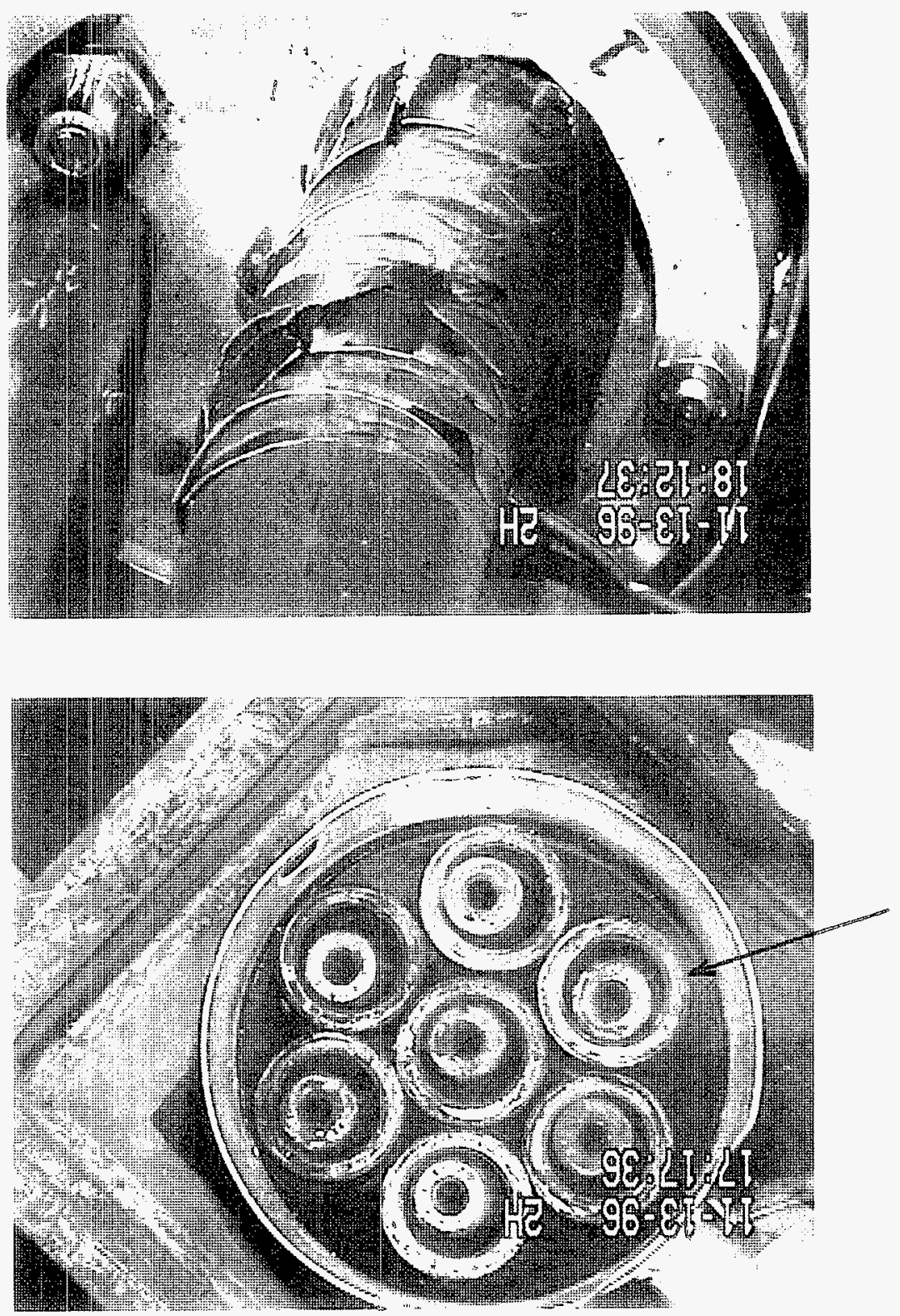


\begin{tabular}{|c|c|c|c|c|c|}
\hline \multicolumn{6}{|c|}{ DISTRIBUTION SHEET } \\
\hline \multirow{2}{*}{$\begin{array}{l}\text { To } \\
\text { Distribution }\end{array}$} & \multirow{2}{*}{\multicolumn{2}{|c|}{$\begin{array}{l}\text { From } \\
\text { Spent Nuclear Fuel } \\
\text { Evaluations / } 2 \text { T650 }\end{array}$}} & & \multicolumn{2}{|l|}{ Page 1 of 2} \\
\hline & & & & \multicolumn{2}{|c|}{ Date $03 / 06 / 97$} \\
\hline \multicolumn{3}{|l|}{ Project Title/Work Order } & & \multicolumn{2}{|c|}{ EDT No. 620783} \\
\hline \multicolumn{3}{|c|}{$\begin{array}{l}\text { Spent Nuclear Fuel Project/Testing of Sludge Coating } \\
\text { Adhesiveness on Fuel Elements in 105-K West }\end{array}$} & & \multicolumn{2}{|l|}{ ECN No. } \\
\hline Name & MSIN & $\begin{array}{l}\text { Text } \\
\text { With All } \\
\text { Attach. }\end{array}$ & Text Only & $\begin{array}{l}\text { Attach./ } \\
\text { Appendix } \\
\text { Only }\end{array}$ & $\begin{array}{l}\text { EDT/ECN } \\
\text { Only }\end{array}$ \\
\hline
\end{tabular}

U.S. Department of Energy,

Richland Operations office

P. G. Loscoe

E. D. Sellers

J. Shuen

G. D. Trenchard

$\begin{array}{ll}57-41 & X \\ 57-41 & X \\ 57-41 & X \\ 57-41 & X\end{array}$

B \& W Protec, Inc.

T. L. Welsh

$\mathrm{T} 4-40 \quad \mathrm{X}$

Fluor Daniel Northwest

L. J. Garvin

R3-15

M. Kummerer

A3-34

D. A. Smith

R3-15

$X$

$X$

ICF Kaiser

G. Baston

R. P. Denise

R3-82

R3-82

$x$

Pacific Northwest National Laboratory

J. Abrefah

A. B. Johnson

S. C. Marschman

P. A. Scott

S. M. Short

$\begin{array}{ll}P 7-27 & X \\ K 8-34 & X \\ P 7-27 & X \\ K 9-46 & X \\ K 7-94 & X\end{array}$

SGN Eurisys Services Corp.
A. L. Pajunen
R3-86
$X$

Wastren

N. R. Roe

$\mathrm{HO}-40 \quad \mathrm{X}$

Duke Engineering \& Services Hanford, Inc.

C. J. Alderman

R. B. Baker

D. W. Bergmann

K. H. Bergsman

A. E. Bridges

W. A. Briggs

L. D. Bruggeman

B. S. Carlisle

S. A. Chastain

R. G. Cowan

C. Defigh Price

D. R. Duncan 


\section{DISTRIBUTION SHEET}

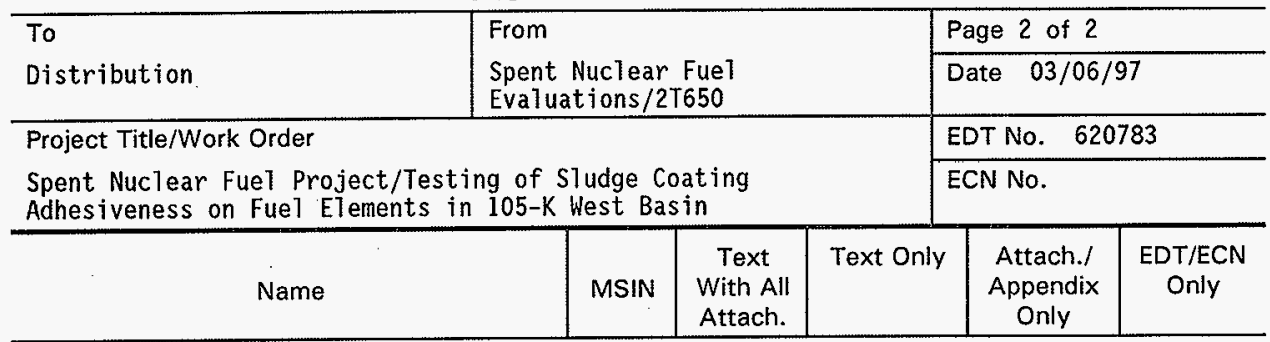

Duke Engineering \& Services, Inc, (Continued)

J. R. Frederickson

L. H. Goldmann

S. L. Hecht

F. G. Hudson

J. J. Jernberg

A. T. Kee

L. A. Lawrence

P. G. LeRoy

D. P. Maassen

B. J. Makenas

R. H. Meichle

W. C. Mills

C. R. Miska

R. P. Omberg

M. J. Packer

T. R. Pauty

K. L. Pearce

A. L. Pitner

R. W. Rasmussen

M. A. Reilly

E. J. Shen

P. K. Shen

D. W. Siddoway

D. W. Smith

J. A. Swenson

D. S. Takasumi

C. A. Thompson

D. J. Trimble

Central Files

DPC
R3-86

R3-86

$\mathrm{HO}-40$

R3-11

$\times 3-72$

R3-86

$\mathrm{HO}-40$

R3-15

$\mathrm{H} 0-40$

$\mathrm{HO}-40$

$\times 3-79$

R3-85

R3-86

$\mathrm{HO}-40$

$\times 3-85$

$\times 3-85$

R3-48

$\mathrm{HO}-40$

R3-86

R3-86

R3-86

HO- 40

$\times 3-71$

R3-15

R3-11

$\times 3-85$

R3-85

HO- 40

A3-88

A3-94

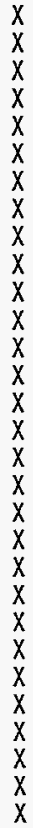

R3-11 X

H0-34 X

R3-86 $X$

R3-85 $X$

R3-85 $X$

K9-46 X 